\title{
Realtà Virtuale e Aumentata per la valorizzazione dell'Historical Archives Museum di Hydra
}

\author{
Marco Medici \\ Federico Ferrari
}

\section{Abstract}

II paper presenta l'esperienza di rilievo, documentazione e valorizzazione dell'Historical Archives Museum a Hydra. Per il rilievo del complesso architettonico si è utilizzata una metodologia ibrida, oggi consolidata, che si avvale sia di strumenti laser scanner che di tecniche fotogrammetriche, anche per la documentazione dei manufatti esposti. Grazie alla creazione di un modello BIM e alla sua integrazione sulla piattaforma INCEPTION, è stato possibile archiviare e collegare modelli di dettaglio di statue, vestiti e altra oggettistica realizzando un modello multiscalare dell'intero complesso museale, sia per fini divulgativi che tecnici. Questa è stata poi la base, mediante opportune ottimizzazioni, per la creazione di ambienti immersivi di Realtà Virtuale e Aumentata per una migliore comprensione e fruizione del valore delle opere museali qui esposte.

\section{Parole chiave}

rilievo, documentazione, virtualità, Virtual Reality, Augmented Reality.

La sinergia tra la piattaforma INCEPTION e i più moderni strumenti per la creazione di realtà immersive, resa possibile dall'impiego di standard interoperabili, permette un fruizione avanzata di contenuti online. Nell'immagine, Nell immagine, un esempio di immagini sferiche recuperabili onthe-fly dalla piattaforma stessa.
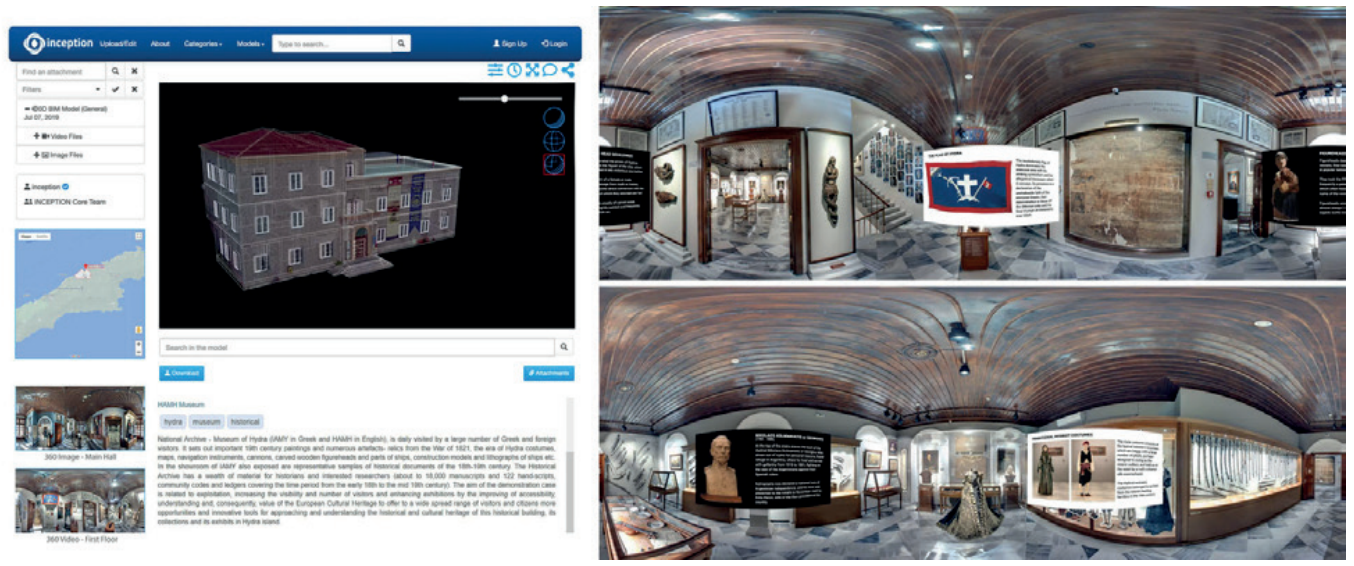


\section{Inquadramento e ambito di indagine}

Il rilievo, la documentazione e la valorizzazione degli spazi e dell'allestimento dell'Historical Archives Museum (HAMH) a Hydra (Grecia) si inquadra nell'ambito dei casi studio del progetto INCEPTION [I] ed è stato realizzato con collaborazione logistico-organizzativa di VBC - Vision Business Consultants. L'obiettivo principale della sperimentazione consisteva nel potenziare e sviluppare strumenti comunicativi a integrazione dei media utilizzati all'interno del museo.

A tal fine, la piattaforma INCEPTION, grazie alle sue potenzialità di integrazione tra modelli tridimensionali e il mondo del Semantic Web, è stata utilizzata come elemento aggregatore di tutte le informazioni specifiche raccolte, descrittive sia di aspetti materiali che immateriali, offrendo inoltre un punto di accesso 3D tramite lo sfruttamento del valore informativo di modelli BIM-based. Questo strumento ha permesso poi il loro impiego sia come ausilio alle strategie di decision making del museo in termini conservativi e per applicazioni web-mobile di realtà virtuale (VR) a scopo turistico-informativo, divulgativo e di marketing culturale.

L'obiettivo primario del caso studio, ancorché basato sulle strategie di valorizzazione digitale, mira ad aumentare la visibilità del sistema museale e delle sue mostre al fine di aumentare il numero di visitatori e offrir loro un miglioramento della comprensione dei percorsi.

Principali obietti e azioni del progetto

A tal fine, si è proceduto secondo le seguenti azioni principali.

I. Identificare parti rappresentative delle collezioni storiche, come dipinti, archivi e mappe, così come l'edificio stesso, da rilevare, fotografare e modellare in 3D, creando una parte del dataset di informazioni digitali di HAMH.

2. Sviluppare, testare e validare un'applicazione mobile che faccia uso di tecnologie AR/ VR per il tour del museo. Infatti, l'utilizzo del modello 3D all'interno di un'applicazione di realtà virtuale può fornire un'esperienza di visita al museo integrativa.

3. Estendere l'uso dei dati a fini gestionali. L'edificio, visto come anche contenitore museale oltre che come bene documentale, necessita anche di una valutazione delle condizioni di esercizio e programmazione delle manutenzioni.

II valore storico-testimoniale del museo e della sua collezione

L'Historical Archives Museum viene formalmente istituito nel 1918 come testimoniato nella Government Gazette dell'Aprile di quell'anno [2] [Adamopoulou-Pavlou 1997, p. 38] per
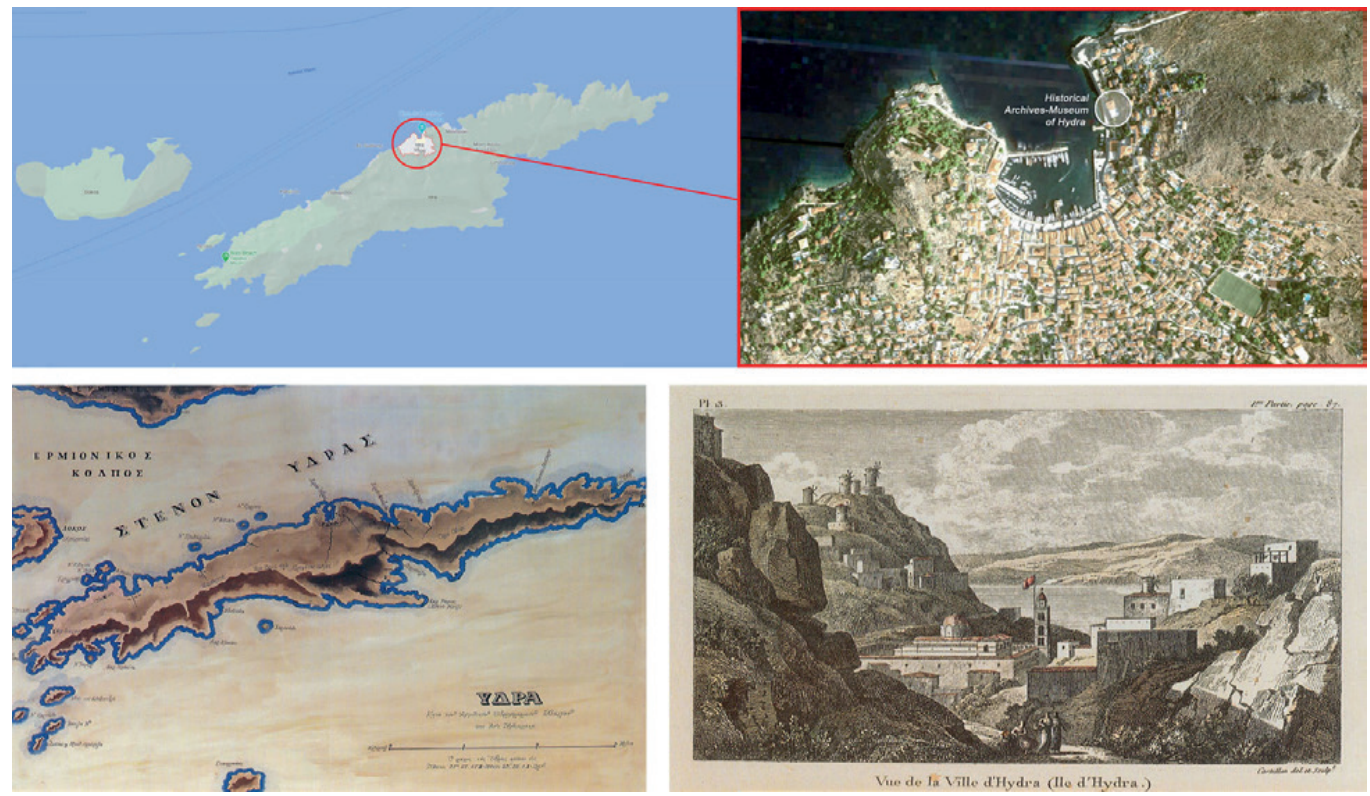
Fig. 2. Collages fototecnici di Albumine (inizio '900) che riprendono il porto di Hydra prima della costruzione del museo (Archivio HAMH 917.5/ $X V / / G e 4712$ e $814.6 /$ $\mathrm{XVI} / \mathrm{Ge} 4734)$.

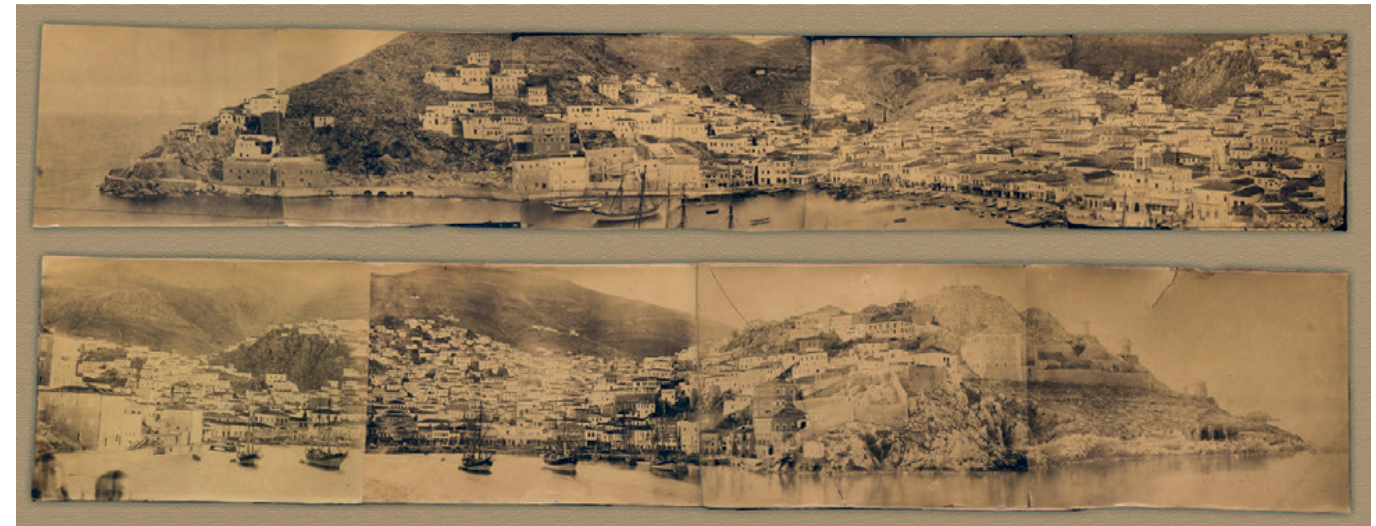

la raccolta e la conservazione del patrimonio culturale dell'isola, grazie all'impegno di due autorità originarie di Hydra: Antonios D. Lignos e Ghikas N. Koulouras.

L'isola infatti ha ricoperto un ruolo fondamentale nella storia della Grecia già a partire dal XVIII secolo quando si sviluppò un'ampia flotta commerciale. Agli inizi del XIX risale la costruzione delle più importanti residenze, proprietà dei ricchi armatori, edifici in pietra a tre o quattro piani (fig. 2).

II primo edificio del museo fu realizzato nel 1919 (fig. 3), progettato dal noto architetto Anastasios Orlandos. Ritenuto però non conforme allo stile architettonico austero e spartano delle architetture presenti sull'isola, il 23 febbraio 1972 l'edificio fu demolito. La costruzione del nuovo progetto, affidato all'architetto idriota Angelos L. Kotronis, segue anche esso un travagliato percorso: la costruzione iniziata nell'ottobre 1975 si conclude con l'allestimento delle sale espositive nel | 995. II nuovo edificio di HAMH viene inaugurato ufficialmente il 6 luglio 1996 (fig. 4).

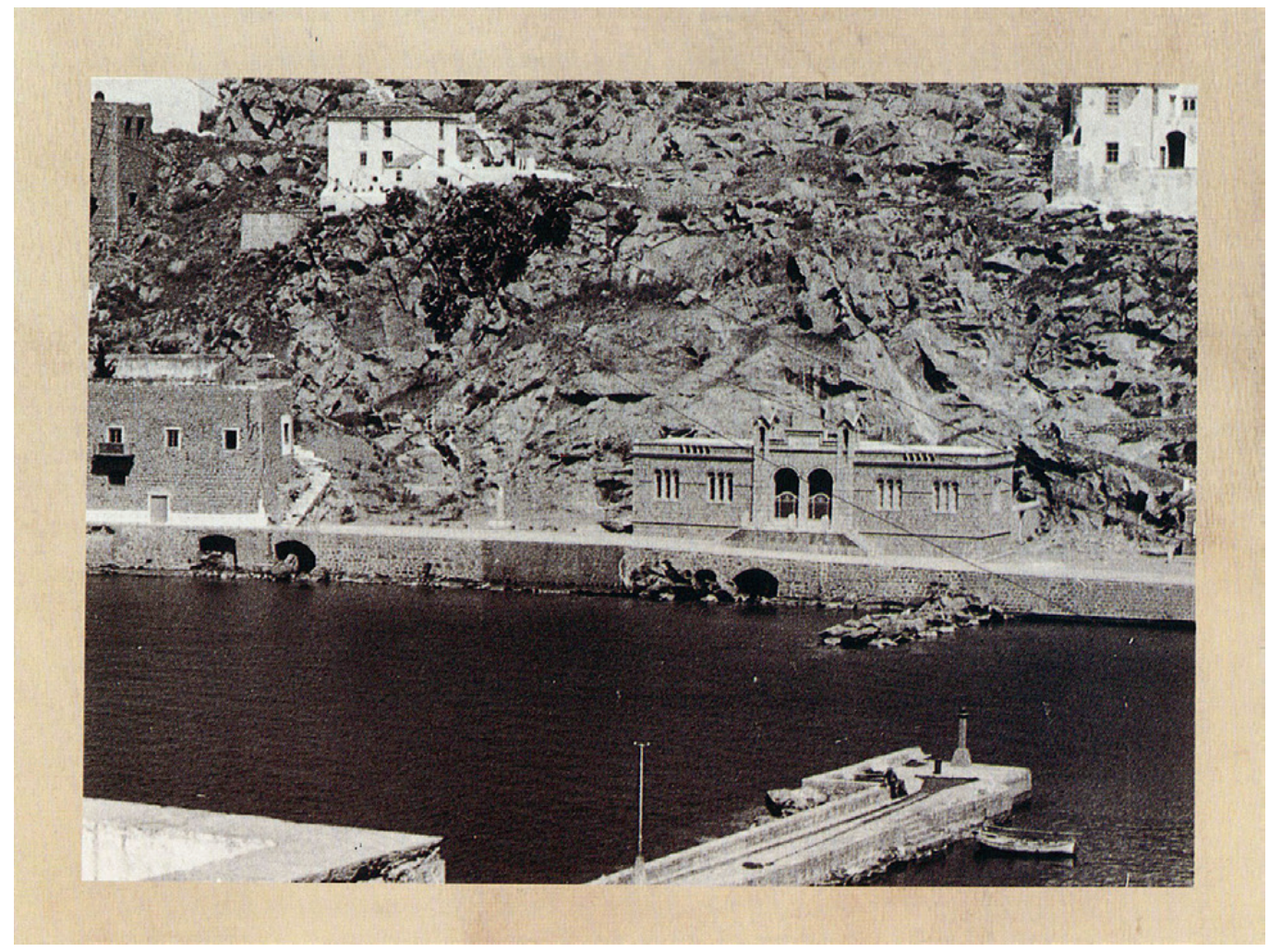

Fig. 3. II primo edificio realizzato come sed museale nel 1919. progettato da Anastasios Orlandos, soffre già costruttivi, che ne determineranno la derlazione nel 972 per lasciare spazıo alla e più grande edificio [Adamopoulou-Pavlou 1997, p. 42]. 

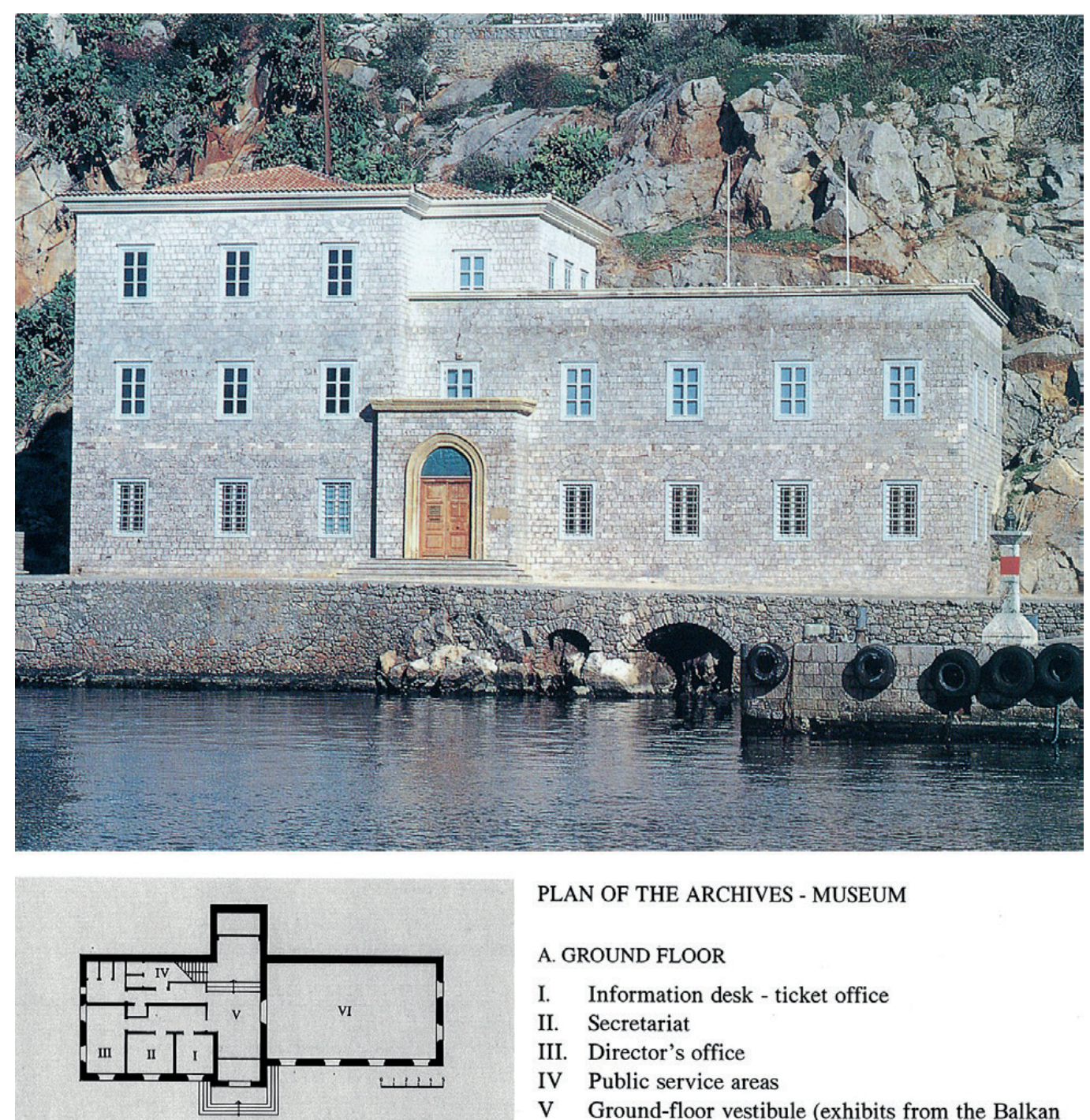

PLAN OF THE ARCHIVES - MUSEUM

A. GROUND FLOOR

I. Information desk - ticket office

II. Secretariat

III. Director's office

IV Public service areas

V Ground-floor vestibule (exhibits from the Balkan

A.

VI Library

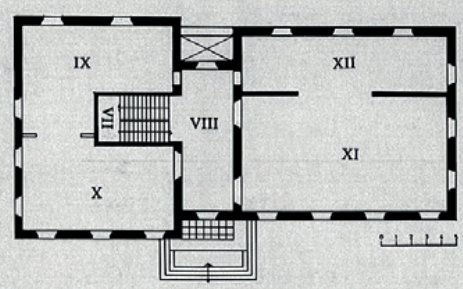

B. FIRST FLOOR

VII Staircase

VIII First-floor vestibule (costumes, figureheads)

IX Archive storage

$\mathrm{X}$ Archive storage - Classification area

XI Large hall of museum exhibits (paintings)

XII Small hall of museum exhibits

B. (paintings - weapons)

Fig. 4. Anche il nuovo edificio, progettato da Hydriot Angelos L. Kotronis, segue un travagliato percorso: la costruzione iniziata nell'ottobre 1975 si conclude con l'allestimento delle sale espositive nel 1995 per essere inaugurato per essere inaugurato 1996 [Adamo 6 luglio Pavlou 1997, pp. 43-45]

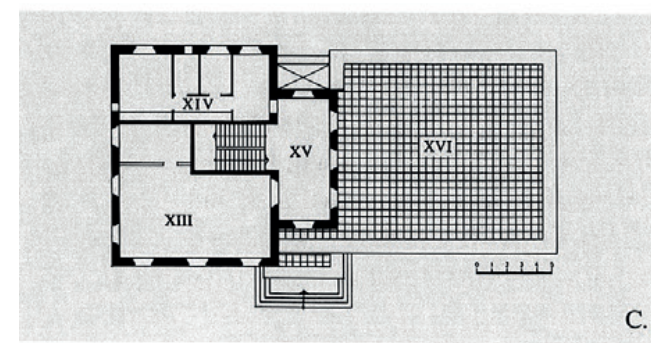

\section{SECOND FLOOR}

XIII Lecture/projection room

XIV Service areas

XV Second-floor vestibule

XVI Roof Terrace

C. (Architectural plans - Angelos L. Kotronis) 
L'ampio edificio (circa 1.000 metri quadrati di superficie), posto sul lato nord del porto di Hydra, si presenta ancora oggi architettonicamente solido e in armonia con l'ambiente circostante e le architetture del luogo, accogliendo ancora turisti e studiosi che vogliono approfondire gli eventi storici e culturali degli ultimi due secoli di questa regione della Grecia. Oggi, il Museo dell'Archivio Nazionale di Hydra viene visitato quotidianamente da un gran numero di visitatori greci e stranieri ed espone importanti dipinti del XIX secolo e numerosi manufatti a cui si aggiungono circa 18.000 manoscritti e 122 codici, libri mastri, ecc. ospitati nell'archivio e che possono essere di particolare interesse per storici e ricercatori [Adamopoulou-Pavlou 20 I5].

\section{Metodologia di rilievo e documentazione tridimensionale}

La complessità sopra descritta ha richiesto una metodologia di rilievo e documentazione tridimensionale che potesse, da un lato, integrare molteplici metodi e strumenti di acquisizione dati e che, dall'altro, ne permettesse la loro aggregazione e il successivo riutilizzo. Per tale motivo si è optato per la realizzazione dei modelli BIM-based utilizzabili sia per la documentazione e gestione dell'edificio che per la realizzazione di applicazioni di AR eVR. Diverse tecniche di acquisizione, integrate tra loro, sono state scelte in funzione degli scopi specifici seguendo le linee guida identificate nel protocollo di rilievo sviluppato all'interno del progetto INCEPTION [Di Giulio et al. 20 I7].

Il rilievo dell'edificio e la sua modellazione BIM

Per il rilievo dell'edificio museale si è utilizzata una metodologia ibrida, oggi consolidata, che si avvale di laser scanner terrestre come base di integrazione della fotogrammetria aerea [Nex, Remondino 20 I4] registrate tramite inquadramento topografico. II laser scanner terreste utilizzato per il rilievo degli interni del museo e per l'esterno dell'intero complesso è stato il Faro LS 330, mentre la fotogrammetria aerea da drone [Fatta et al. 2017], per il modello delle coperture e delle parti del complesso in elevazione difficilmente raggiungibili a causa dell'orografia del terreno e della vegetazione, è stata svolta mediante acquisizione fotografica da DJI Mavic Pro.

II rilievo laser scanner terreste (98 scansioni con 9,3 mm errore residuo) è stato registrato direttamente sulla rete topografica esistente (materializzata con capisaldi in loco sia in esterno che nel salone principale). II modello così ottenuto è servito, insieme ai capisaldi topografici visibili dal drone (n. 5), come appoggio alla procedura di allineamento alla foto-modellazione (per un totale di 483 immagini processate) per migliorare la precisione e ridurre gli errori di deriva (fig. 5).

Tale rilievo ha poi permesso di procedere con una modellazione BIM architettonica, realizzata con il software Autodesk Revit 2016. II modello, sviluppato con un LOD adeguato all'inclusione di tutte le informazioni derivanti dai rilievi dell'edificio così come dalla documentazione manufatti qui contenuti, è stato pertanto strutturato con una organizzazione informativa che potesse permettere di essere utilizzato dal museo e dai tecnici in sostituzione dei disegni 2D CAD esistenti, per scopi gestionali e manutentivi.

Integra la documentazione, anche a integrazione del modello BIM, una campagna fotografica, composta da 56 foto sferiche $360^{\circ}$, per la costruzione di un Virtual Tour del complesso in applicazioni off-site, principalmente legate al web-browsing. Le immagini alta risoluzione (equirettangolare da $10.000 \times 5.000 \mathrm{px}$ ) sono state acquisite in HDR tramite Ntech iStar. II Virtual Tour è stato poi realizzato con 22 delle immagini acquisite e successivamente popolate delle informazioni contestuali.

La documentazione 3D dei manufatti della collezione museale

Particolare attenzione è stata rivolta alla documentazione 3D dei manufatti all'interno del museo e la creazione dei loro modelli digitali. Per l'acquisizione sono state impiegate sia tecnologie laser scanner (Faro Ls330) per le gli apparati decorativi e dettagli di scala architettonica (come modanature e porte di accesso alle ricche abitazioni dell'isola o apparati 
relativi a imbarcazioni o alla navigazione in genere), sia tecniche fotogrammetriche (Canon 5D Mark2 - 50mm fl,4) per la statuaria, la customistica e l'oggettistica. In entrambi i casi ci si è awalsi dell'uso di target per la registrazione e il processamento dei dati.

Complessivamente i manufatti oggetto della campagna di documentazione e dei quali sono stati creati modelli tridimensionali ammontano a circa una trentina, scelti tra quelli con il significato simbolico più importante [Adamopoulou-Pavlou 20I5]. Tra questi una polena rappresentante una figura femminile in stile vernacolare che culla tra le braccia un piccolo leone, diversi akrostolia, (decorazioni della prua), cinque costumi tradizionali idrioti, alcune pistole della collezione dell'HAMH, un elaborato vaso d'argento intitolate all'ammiraglio Miaoulis e il busto dell'idriota Nikolaos Kolmaniatis.

L'arricchimento semantica del modello BIM e la popolazione con documentazioni allegata II modello BIM architettonico realizzato diviene quindi l'elemento aggregatore di tutta la digitalizzazione degli artefatti e ne rende possibile il loro collegamento sia digitale che di significato, grazie allo sfruttamento del Semantic Web. II modello, compatibile con lo standard IFC 2×3, è stato infatti caricato sulla piattaforma INCEPTION [Maietti et al. 2020], dove sono stati convertiti in TTL [Bonsma et al. 2018] tutte le componenti modellate, sia architettoniche che di arredo espositivo, per essere ulteriormente arricchite sia semanticamente sia

Fig. 5. II rilievo dell'intero complesso del Museo è stato effettuato utilizzando con una metodologia ibrida, integrando i dati da laser scanner terrestre con quelli della

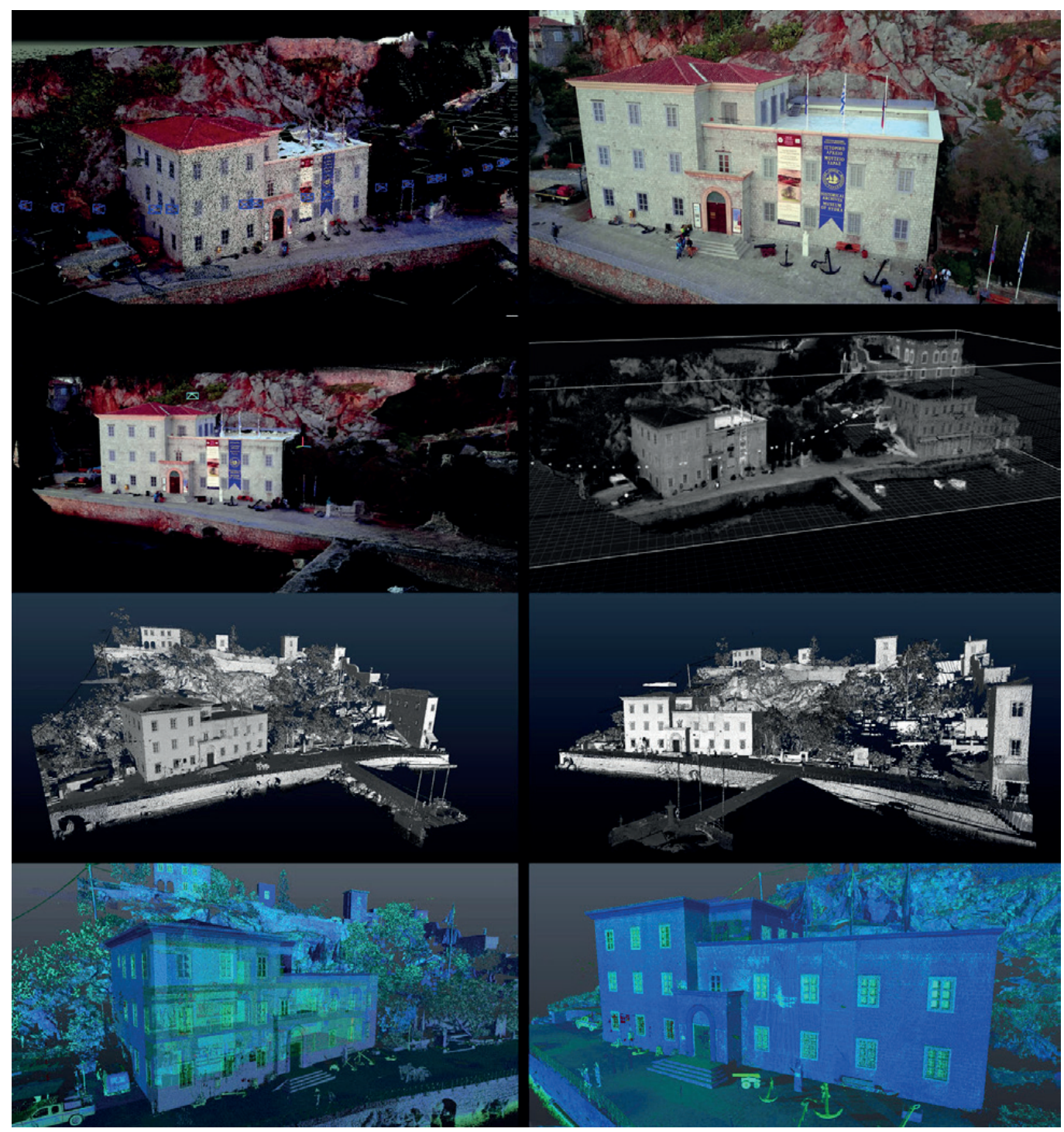




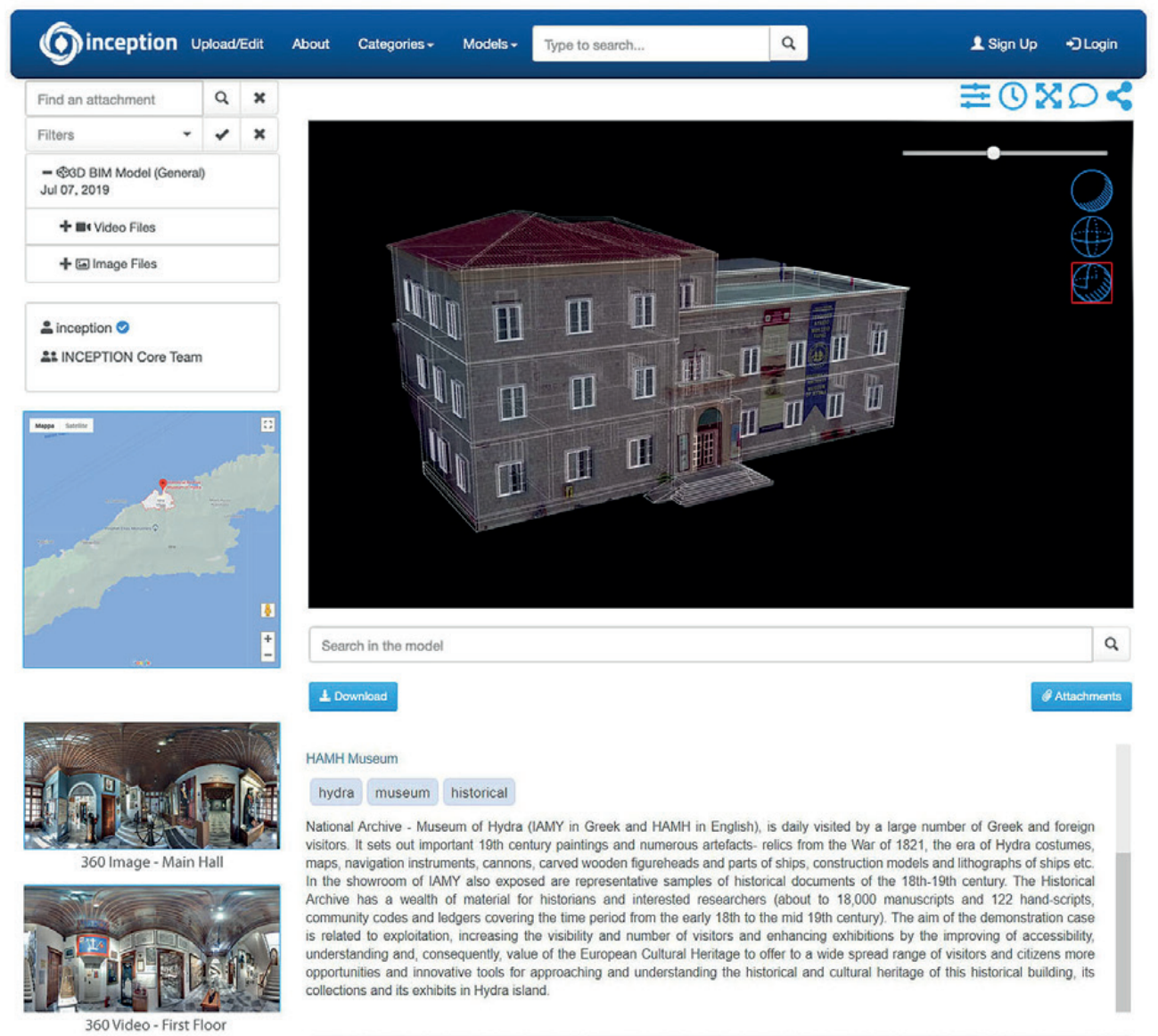

Fig. 6. II modello BIM, realizzato con il software Autodesk Revit 2016 è stato Revit 2016, estato caricato alinterno della piattaforma INCEPTION per essere arricchito semanticamente e per collegare allegati ai singoli elementi. Nell'immagine, uno screenshot della piattaforma in modalità di visualizzazione blended tra modello BIM e il rilievo $3 \mathrm{D}$.
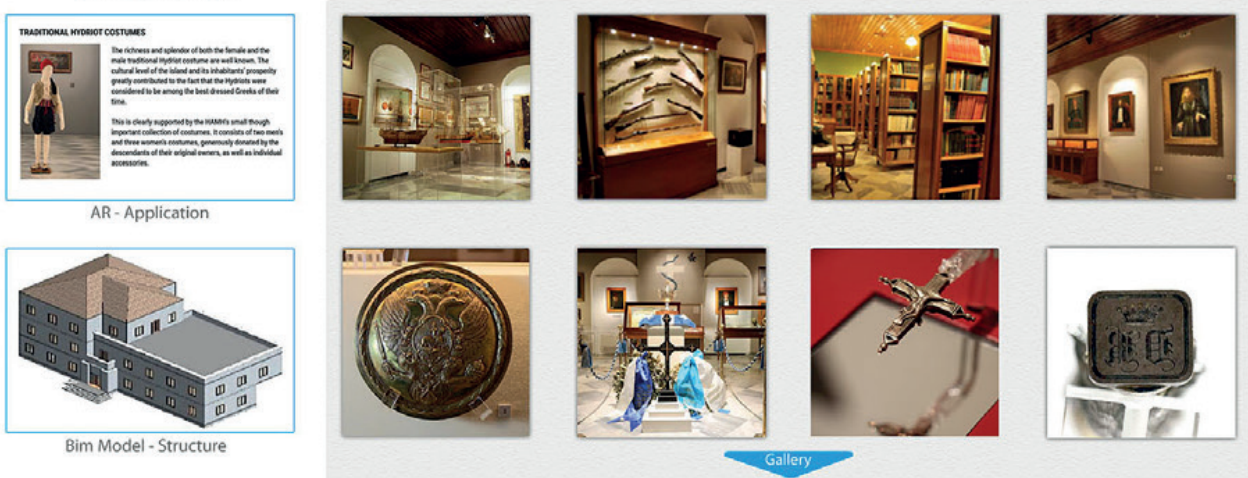

con allegati di diverso tipo (PDF, relazioni strutturali, termografie, immagini, modelli 3D di dettaglio, ecc.), riferiti ai singoli elementi del modello BIM. A singolo oggetto tridimensionale è quindi attributo un URI (Unique Reference Identifier) che, posto alla base del sistema delle triple semantiche, rende possibile riferire in maniera univoca a ogni elemento le informazioni già contenute nel file IFC, gli allegati successivamente collegati mediante la piattaforma, nonché eventuali collegamenti diretti con archivi storici resi disponibili come Open Linked Data.

La diversità dei modelli e la complessità informazioni contenute richiedono però, al tempo stesso, un efficace sistema di fruizione (fig. 6). In tal senso, la piattaforma INCEPTION può filtrare le diverse tipologie di dati in funzione della tipologia utenti. In questo caso, poiché sono disponibili informazioni su dati tecnici e/o operativi, il tecnico del museo può, ad esempio, facilmente scegliere tra le informazioni importanti per la 
valutazione delle condizioni della struttura o la programmazione della manutenzione, mentre lo studioso può decidere di visualizzare le sole informazioni storico-archivistiche collegate alla geometria, la documentazione fotografica 360 degli ambienti o le digitalizzazioni degli artefatti.
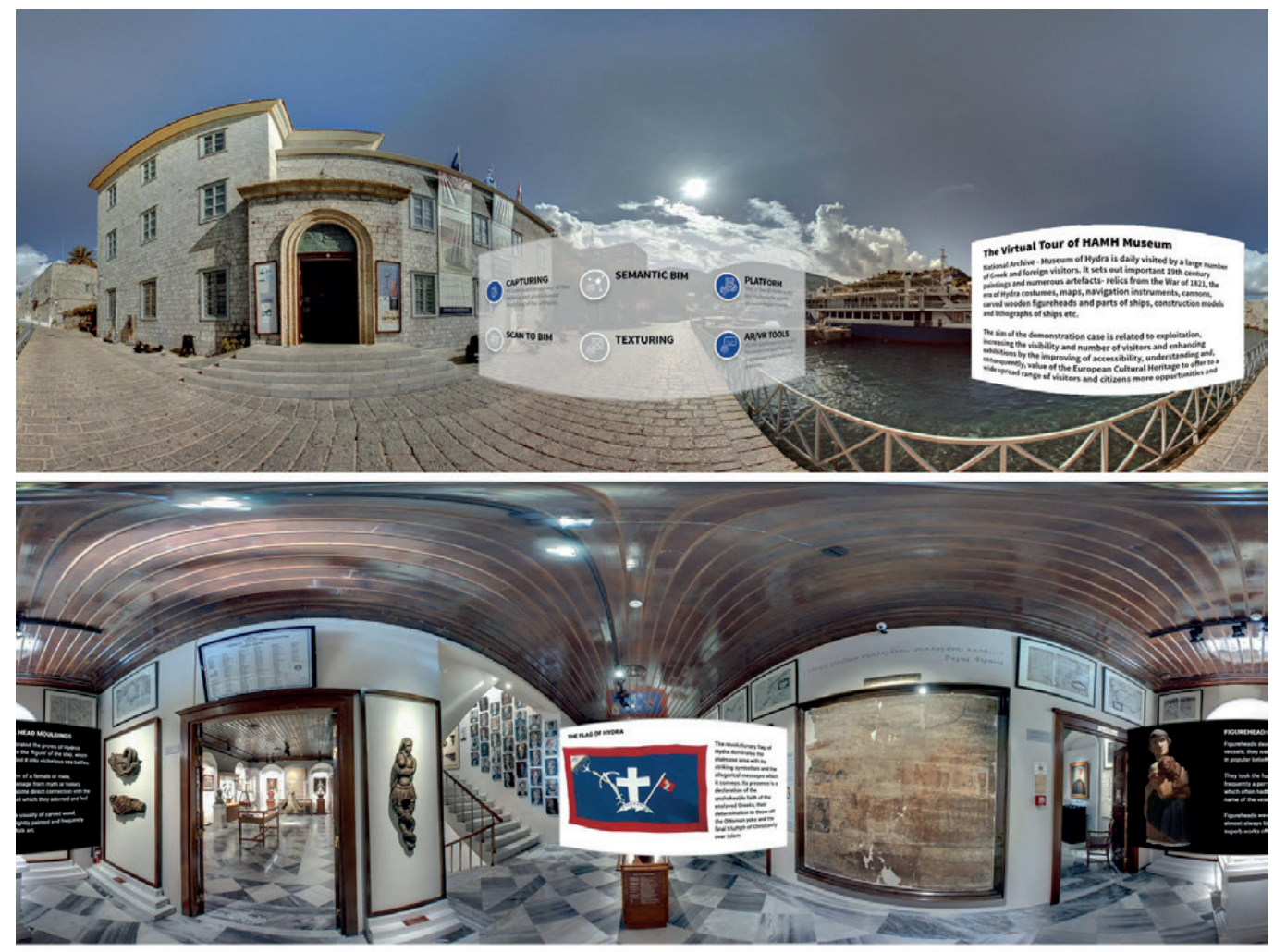

Fig. 7. II Virtual Tour del museo interattivo è stato realizzato con 22 delle 56 foto sferiche $360^{\circ}$, acquisite durante la campagna di rilievo, ed è stato pensato principalmente per l'utilizzo via browser web, headset VR allin-one o dispositivi mobile.
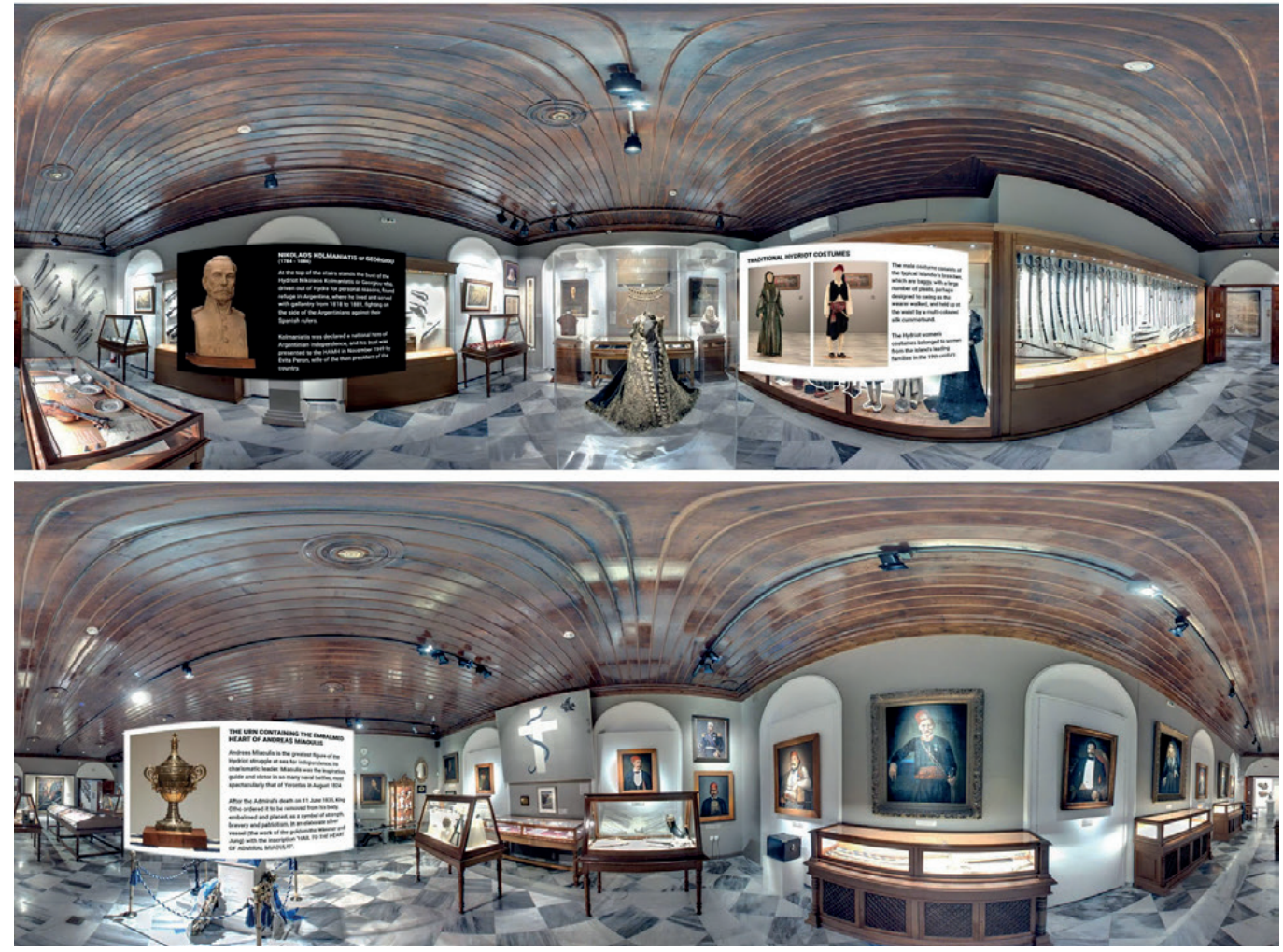


\section{Risultati e applicazioni di AR/VR per la fruizione dei contenuti documentati}

A partire del rilievo e dal modello BIM, nell'integrazione con i modelli di dettaglio di statue, vestiti e altra oggettistica esposta nella collezione del museo, resa possibile dall'integrazione della piattaforma INCEPTION, si realizzato in maniera concreta un modello multiscalare dell'intero complesso museale. Lo stesso ha quindi aperto alla realizzazione di ulteriori esperienze di fruizione dei dati, anche grazie alla creazione di applicazioni di realtà Virtuale (VR) o Aumentata (AR) [Parrinello et al. 20।6]. In alcuni casi i modelli già realizzati sono stati ulteriormente processati, ottimizzati e ridefiniti tramite modellatori per superfici, anche NURBS, come Rhino o Sketchup [Ausonio et al. 20 I8].

Nella configurazione dei modelli è stato di fondamentale importanza la definizione a priori della logica di storytelling che la comunicazione in ARVR avrebbe sviluppato [Keil et al. 2013]. La navigazione del Virtual Tour del museo e della collezione museale qui contenuta, fruibile sia da desktop che da mobile e con la possibilità di attivare una modalità immersiva (con Head-Mounted Display HMD di tipo fisso o portatile), ha permesso di porre l'accento sulla narrazione grazie alla possibilità di guidare l'utente tra le stanze rispetto a un percorso predefinito e disponendo contenuti aggiuntivi stanza per stanza con maggiore facilità. Nel Virtual Tour prodotto, realizzato in modalità raster-based a partire dalle foto $360^{\circ}$ (fig. 7), gli oggetti prendono vita e richiamano l'attenzione del visitatore digitale mediante l'impiego di pop-up tridimensionali. Inoltre, la visita on-site è stata arricchita mediante lo sviluppo di un'app AR per smartphone (fig. 8) che valorizza la visualizzazione degli artefatti grazie al loro riconoscimento nella collezione museale sulla base di forma, dimensione, aspetto e localizzazione. La tecnologia di riconoscimento utilizzata è basta sugli algoritmi resi disponibili da Vuforia per lo sviluppo in ambiente Unity. Grazie alla disponibilità di una connessione 4G o Wi-Fi (entrambe disponibili sul posto), gli oggetti della collezione museale diventano quindi punti di accesso [Brusaporci et al. 20 I7] per la fruizione di contenuti online aggregati sulla piattaforma INCEPTION che, in tal modo, vengono da lì direttamente e dinamicamente prelevati, nella loro versione più aggiornata, sfruttando una logica di recupero on-the-fly.

\section{Conclusioni e sviluppi futuri}

Il caso studio della digitalizzazione di HAMH ha permesso di dimostrare come una efficace sinergia tra importati innovazioni tecnologiche e piccoli sistemi museali locali possa funzionare solo se facilitata da specifici attori, ruolo in questo caso svolto da VBC. Sebbene il potenziale delle applicazioni di AR e VR nel settore dei beni culturali e in particolare in quello museale sia comprovato e migliori l'esperienza di visita, non sempre la singola amministrazione museale è in grado di accedere a tali vantaggi. II ruolo fondamentale di un facilitatore informato ha in questo caso reso disponibile l'adozione delle più moderne tecnologie in maniera consapevole.

In conclusione, sebbene non sia possibile allo stato attuale fornire dati significati sull'aumentata visibilità di questo sistema museale e delle sue mostre o sull'aumentare il numero di visitatori anche in virtù dell'attuale condizione pandemica, anche la sola possibilità di poter apprezzare gli oggetti esposti in un periodo storico di riduzione della mobilità globale è elemento di valutazione favorevole del progetto stesso. Inoltre, è possibile affermare che, con una maggiore disponibilità di prodotti e servizi che il museo può offrire proprio in virtù di questa digitalizzazione, si è di certo ampliata la base potenziale di utenti con cui HAMH si può relazionare. Resta di certo l'utente principale del museo il visitatore stagionale che si trova sull'isola di Hydra per una breve soggiorno di piacere, ma a questo si aggiungono in maniera decisamente più consistente rispetto a prima il visitatore digitale interessato alla comprensione della più recente storia della Grecia così come lo studioso internazionale che, per la prima volta, può accedere a contenuti unici prima disponibili solo in loco.

In ultimo, le tecniche di digitalizzazione tridimensionale combinate con il web e gli strumenti di XR (Extended Reality) divengono nuovo strumento lessicale di dialogo e racconto per differenti attori, aprendo efficaci riutilizzi per finalità multidisciplinari. 
Fig. 8. Esempio di sviluppo di applicazione di realtà aumentata AR sul busto del Capitano Nikolaou G. Kolmaniati (Nicolas Jorge Colmaniatis) che, dopo essere immigrato in

Argentina nel $|8| \mid$ si arruolò marinaio e raggiunse il grado di contrammiraglio, un Idriota eroe nazionale d'Argentina.
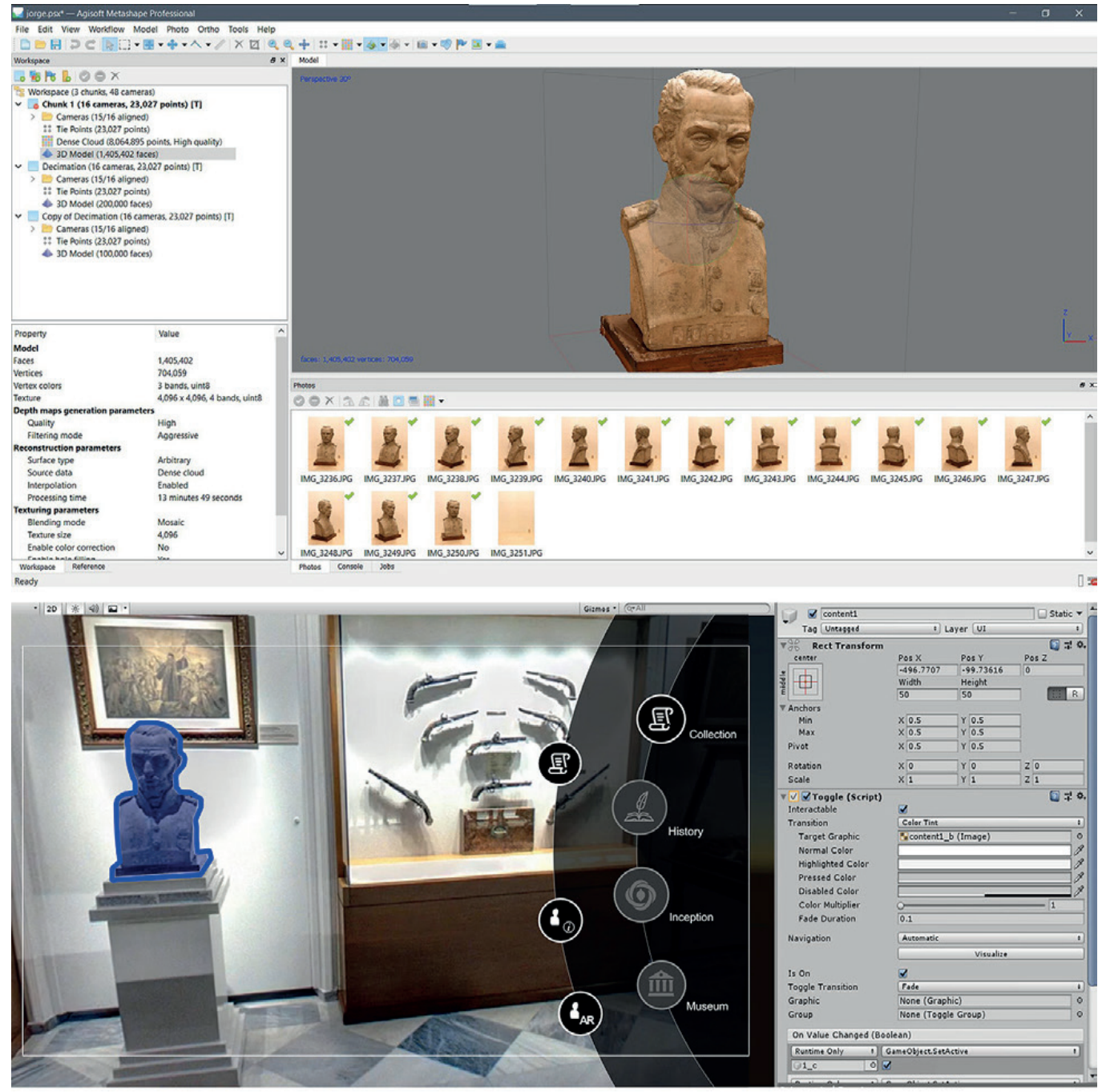

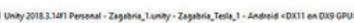

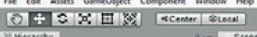

$+11$
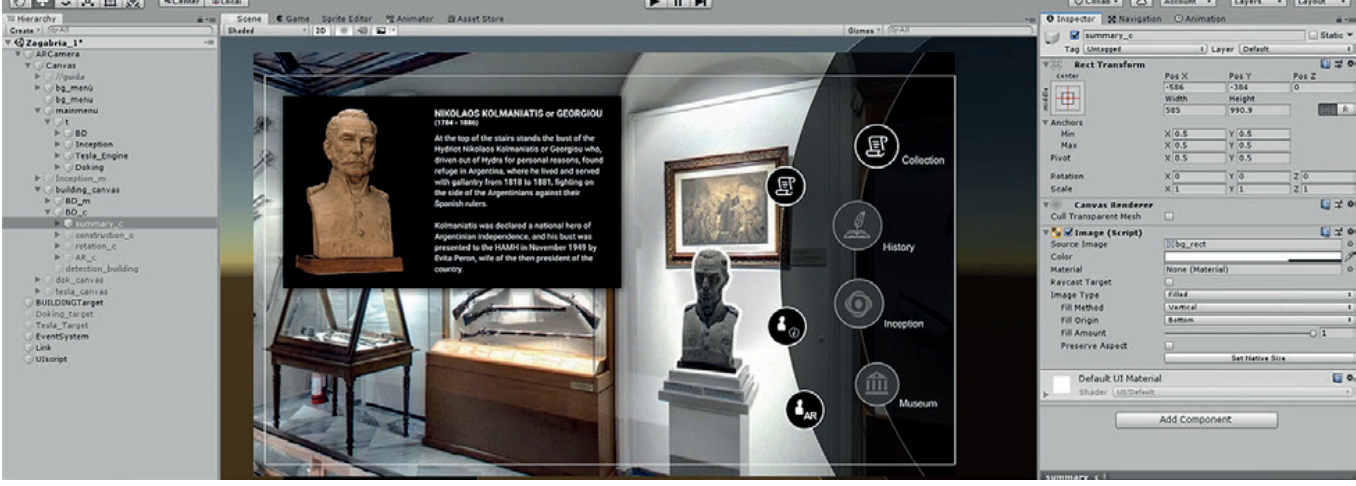

Note

[I] Sperimentazione effettuata all'interno del progetto europeo INCEPTION - Inclusive Cultural Heritage in Europe through 3D semantic modelling, conclusosi a Maggio 2019 e finanziato della Commissione Europea nell'ambito del Programma Horizon 2020, Research and Innovation Action sotto il Grant Agreement No. 665220.

[2] Government Gazette, n. 82, 16 April 1918. 


\section{Riferimenti bibliografici}

Adamopoulou-Pavlou C. (1997). Hystorical Archives - Museum Of Hydra. Atene, Greece: Artigraf.

Adamopoulou-Pavlou C. (200I). Hydra. Hydra, Greece:Vergas.

Adamopoulou-Pavlou C. (2015). Catalogue of H.A.M. of Hydra. Hydra, Greece: HAMH.

Ausonio E. et al. (2018). Potenzialità dei software Free e/o Open Source per la modellazione, gestione e fruizione di entità 3D In Geomatics Workbooks, n. 14 - FOSS4G-it, pp. 4-20.

Bonsma P. et al. (20 I 8). Handling huge and complex 3D geometries with Semantic Web technology. In IOP Conference Series: Materials Science and Engineering, vol. vol. 364012041 , pp. I-7.

Brusaporci S. et al. (2017) Augmented Reality for Historical Storytelling. The INCIPICT Project for the Reconstruction of Tangible and Intangible Image of L'Aquila Historical Centre. In Proceedings, I, I083.

Di Giulio R. et al. (20 I7). Integrated data capturing requirements for 3D semantic modelling of Cultural Heritage: the INCEPTION protocol. In Int. Arch. Photogramm. Remote Sens. Spatial Inf. Sci., XLII-2MW, pp. 25 I-257.

Fatta F., Bassetta M., Manti A. (2017). Survey Methodologies, Research and Technological Innovation for a Case of Medieval Archaeology: Torre Melissa in the province of Crotone. In Disegnarecon, I0(19), pp. 6. I - 6. 17

Keil J. et al. (20।3). A digital look at physical museum exhibits: Designing personalized stories with handheld Augmented Reality in museums. In Digital Heritage International Congress, vol. 2, pp. 685-688.

Maietti F. et al. (2020). Documentation, Processing, and Representation of Architectural Heritage Through 3D Semantic Modelling:The INCEPTION Project. In C. Bolognesi, C. Santagati (Eds.). Impact of Industry 4.0 on Architecture and Cultural Heritage, pp. 202-238. Hershey, PA: IGI Global.

Nex F., Remondino F. (20 I4). UAV for 3D mapping applications: a review. In Applied geomatics, 6( I), pp. I-I5.

Parrinello S., Picchio F., Bercigli M. (20|6). La 'migrazione' della realtà in scenari virtuali: Banche dati e sistemi di documentazione per la musealizzazione di ambienti complessi. Musei virtuali dell'architettura e della città. In Disegnarecon, 9( 17), pp. I4- I.

Spiliotis S.F. (1998). The secret Hydra. Hydra, Greece: Kyveli.

\section{Autori}

Marco Medici, Università di Ferrara, marco.medici@unife.it

Federico Ferrari, Università di Ferrara, federico,ferrari@unife.it

Per citare questo capitolo: Medici Marco, Ferrari Federico (2021). Realtà Virtuale e Aumentata per la valorizzazione dell'Historical Archives Museum di Hydra/Virtual and Augmented Reality Applications for Enhancement of the Historical Archives Museum of Hydra. In Arena A Aren M. Mediati D. Raffa P. (a cura di) Connettere Un disegno per annodare e tessere Linguggi Distanze Tecnologie Atti del $42^{\circ}$ Convegno Internozionale dei Docenti delle Discipline deelo Roppresen 42th International Conference of Representation Disciplines Teachers. Milano: FrancoAngeli, pp. 247 I-2492. 


\title{
Virtual and Augmented Reality Applications for Enhancement of the Historical Archives Museum of Hydra
}

\author{
Marco Medici \\ Federico Ferrari
}

\section{Abstract}

The paper presents the experience of survey, documentation, and valorization of the Historical Archives Museum in Hydra. For the survey of the architectural complex, a hybrid methodology was used, nowadays consolidated, which uses both laser scanner tools and photogrammetric techniques, also for the documentation of the exposed artifacts. Furthermore, thanks to the creation of a BIM model and its integration on the INCEPTION platform, it was possible to store and connect detailed models of statues, clothes, and other objects, creating a multiscale model of the entire museum complex, both for popular and technical purposes. This model was then the basis, through appropriate optimizations, to create immersive environments of Virtual and Augmented Reality for a better understanding and enjoyment of the value of the museum works exhibited here.

Keywords

surveying, documentation, virtuality, Virtual Reality, Augmented Reality.

The synergy between the INCEPTION platform and the most modern tools for the creation of immersive realities, made possible by the use of interoperable standards, allows an advanced fruition of advanced frution of Online contents. In the image, an example of spherical images that can be retrieved on-the-fly
from the platform.
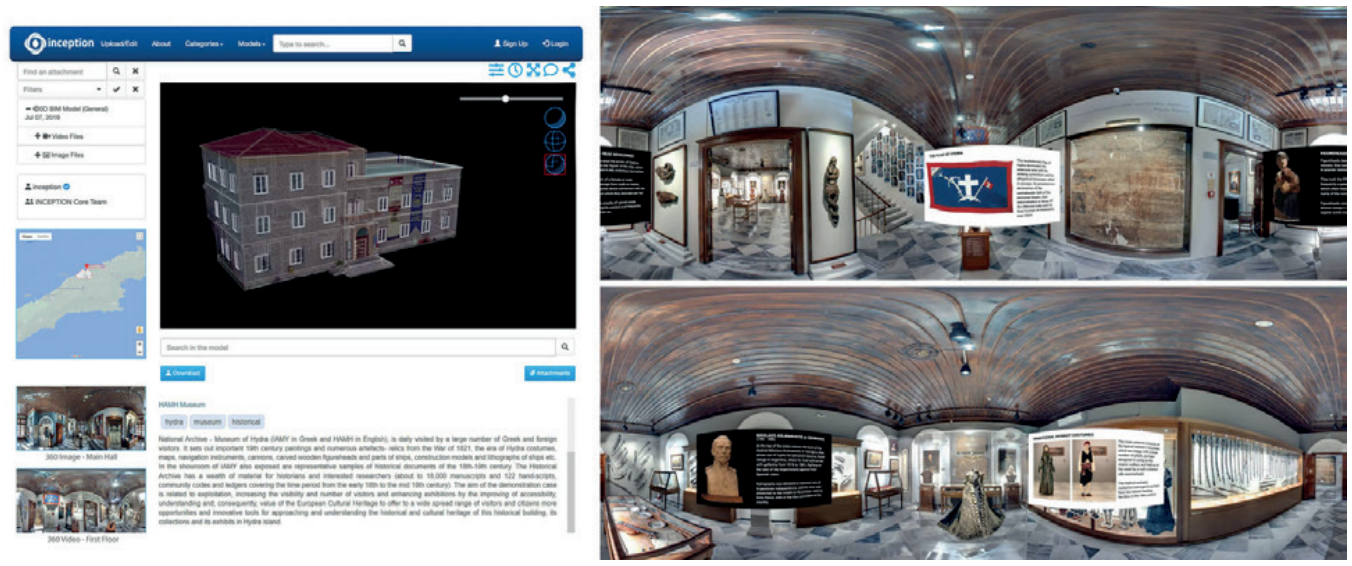


\section{Framework and scope of the investigation}

The survey, documentation, and enhancement of the spaces and the layout of the Historical Archives Museum (HAMH) in Hydra (Greece) is part of the case studies of the INCEPTION project [I] and was carried out with the logistical and organizational collaboration of VBC - Vision Business Consultants. The main objective of the experimentation was to strengthen and develop communication tools to integrate the media used within the museum.

To this end, the INCEPTION platform, thanks to its potentiality of integration between three-dimensional models and the Semantic Web world, has been used as an aggregator element of all the specific information collected, descriptive of both material and immaterial aspects, offering also a 3D access point through the exploitation of the informative value of BIM-based models. This tool has then allowed their use both to aid the museum's decision-making strategies in terms of conservation and for web-mobile applications of virtual reality (VR) for tourism-informative, dissemination, and cultural marketing purposes.

Although based on digital enhancement strategies, the primary objective of the case study is to increase the visibility of the museum system and its exhibitions to increase the number of visitors and offer them a better understanding of the routes.

Main objectives and actions of the project

To this end, the following main actions were taken.

I. Identify representative parts of the historical collections, such as paintings, archives, and maps, as well as the building itself, to be surveyed, photographed, and modeled in 3D, creating a part of HAMH's digital information dataset.

2. Develop, test, and validate a mobile application that uses ARVR technologies for museum tours. Using the 3D model within a virtual reality application can provide an integrative museum tour experience.

3. Extend the use of data for management purposes. The building, seen as a museum container and a documentary asset, also needs an evaluation of its operating conditions and maintenance schedule.

The historical-testimonial value of the museum and its collection

The Historical Archives Museum was formally established in 1918 as witnessed in the Government Gazette of April of that year [2] [Adamopoulou-Pavlou 1997, p. 38] for the collec-
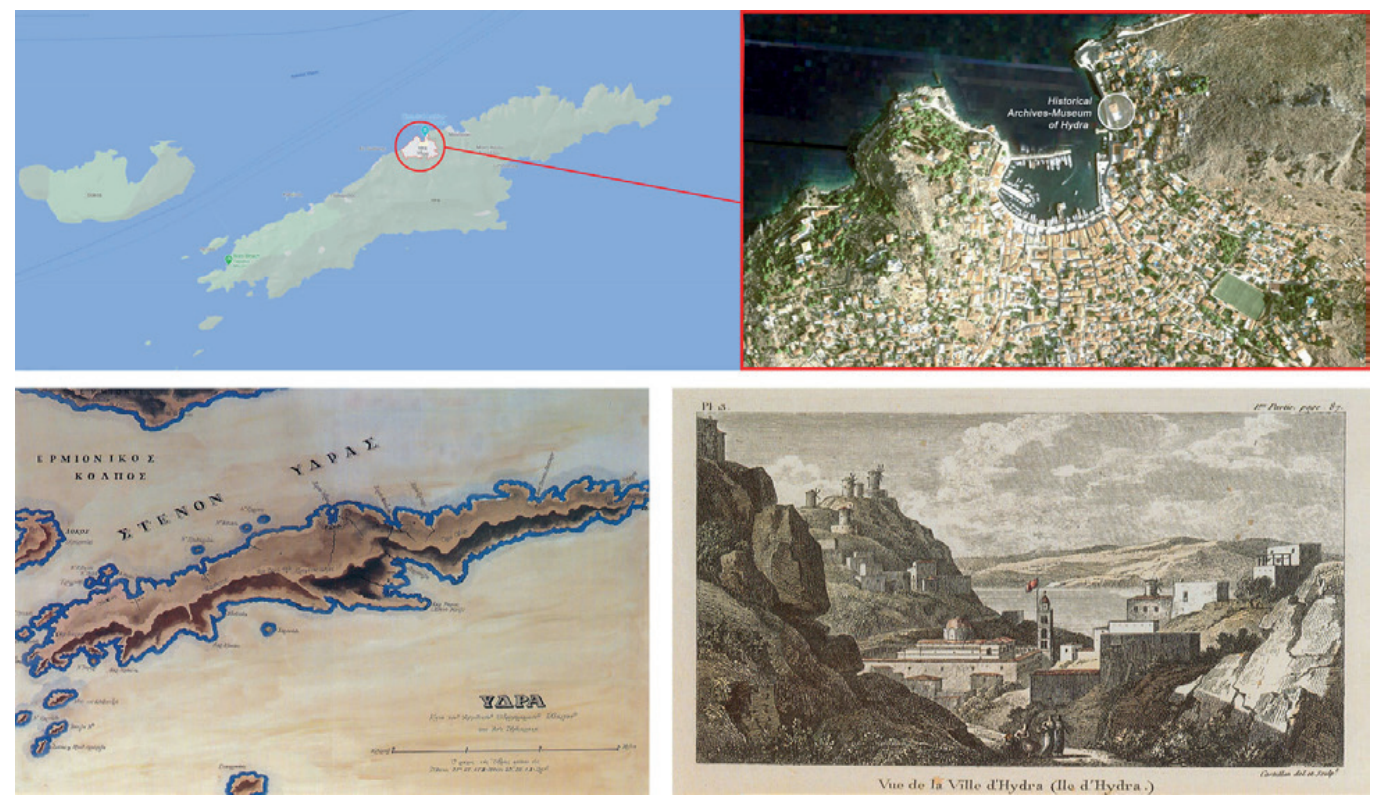
Fig. 2. Photographic collages by Albumine (early 20th century) showing the port of Hydra before the construction of the museum (HAMH Archives 917.5/XVI Ge47|2 and $814.6 / \times V \mid$ Ge4712 and
Fig. 3. The first building constructed as the museum's headquarters in 1919, designed by Anastasios Orlandos, suffered from significant construction problems as early as its construction, which led to its demolition in 1972 to make way for the construction of a new, larger building [ 1997. Adamopoulou-Pavlou, p. 42].

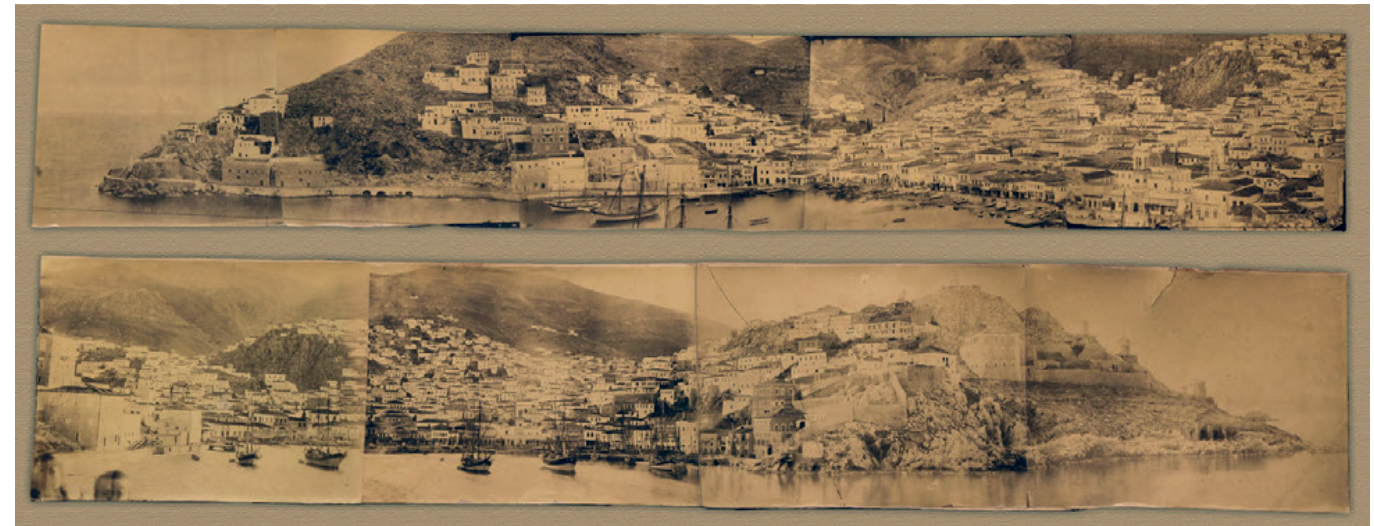

tion and preservation of the island's cultural heritage, thanks to the efforts of two authorities originally from Hydra: Antonios D. Lignos and Ghikas N. Koulouras.

The island played a fundamental role in the history of Greece since the $18^{\text {th }}$ century, when a large commercial fleet developed. At the beginning of the XIX century dates the construction of the most important residences, property of the wealthy shipowners, stone buildings with three or four floors (fig. 2).

The first museum building was constructed in 1919 (fig. 3), designed by the renowned architect Anastasios Orlandos. However, since it was not considered in keeping with the island's architecture's austere and spartan architectural style, the building was demolished on February 23, 1972. The construction of the new project, entrusted to the Idriot architect Angelos L. Kotronis, also followed a troubled path: the construction began in October 1975 and ended with installing the exhibition halls in 1995. The new building of HAMH was officially inaugurated on July 6, 1996 (fig. 4).

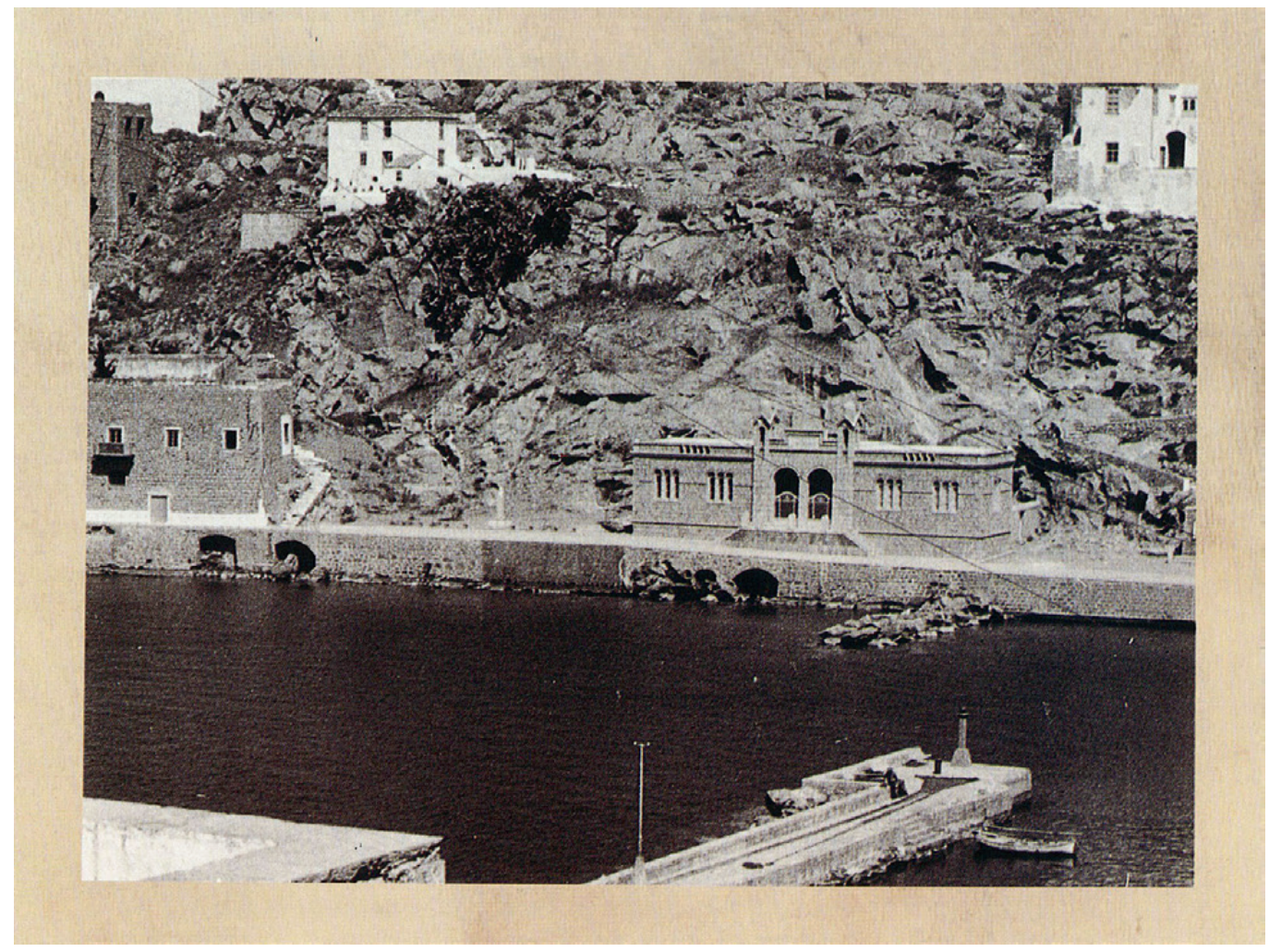



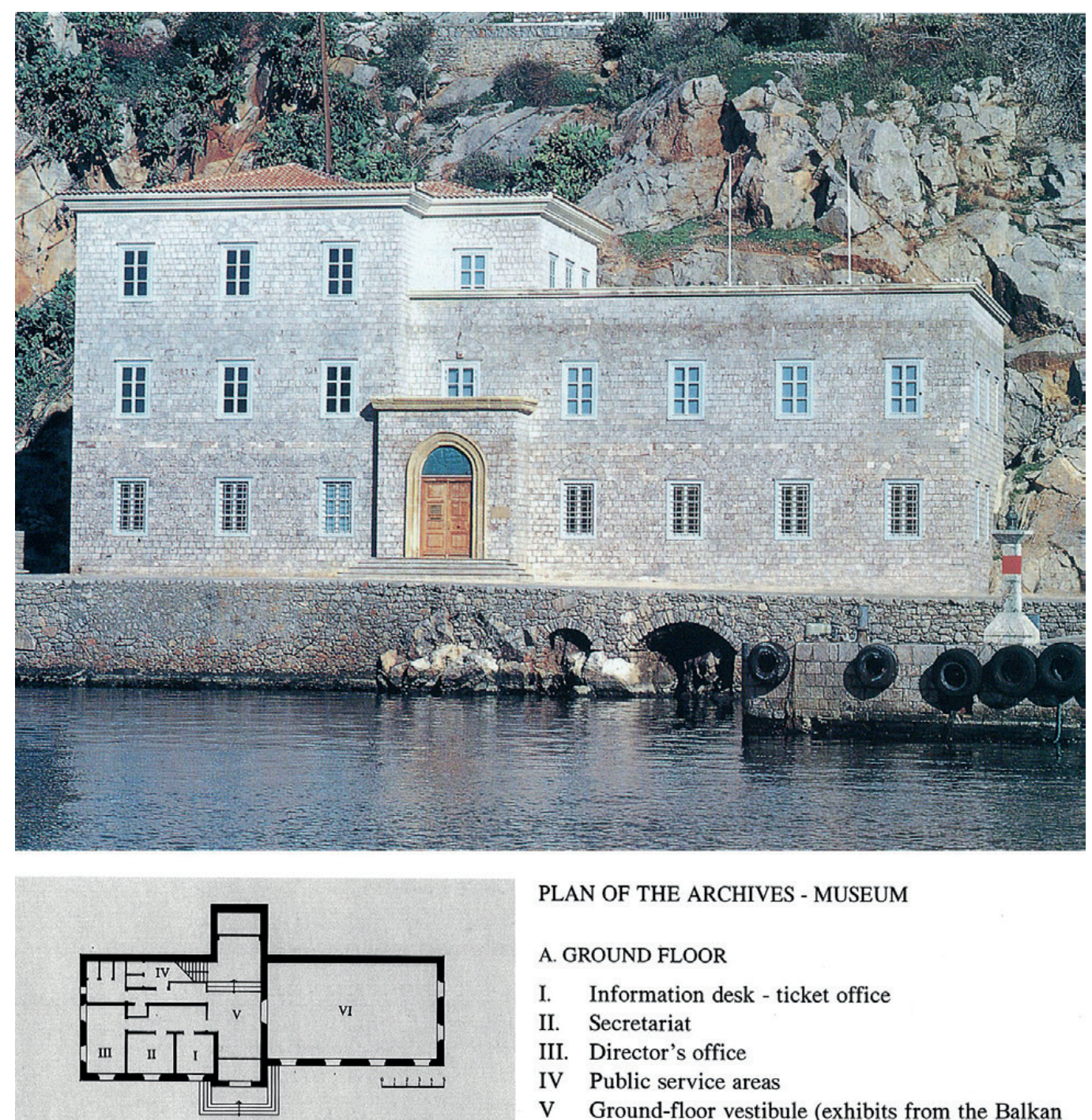

PLAN OF THE ARCHIVES - MUSEUM

A. GROUND FLOOR

I. Information desk - ticket office

II. Secretariat

III. Director's office

IV Public service areas

A.

V Ground-floor vestibule (exhibits from the Balkan Wars and World War I and II)

VI Library

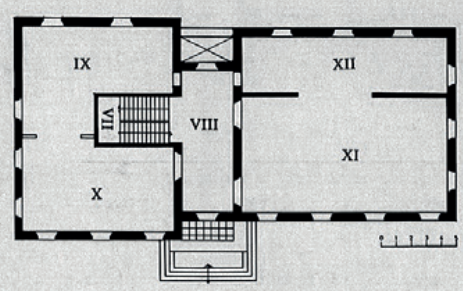

B. FIRST FLOOR

VII Staircase

VIII First-floor vestibule (costumes, figureheads)

IX Archive storage

$\mathrm{X}$ Archive storage - Classification area

XI Large hall of museum exhibits (paintings)

XII Small hall of museum exhibits

B. (paintings - weapons)

Fig. 4.The new building designed by Hydriot Angelos L. Kotronis, also followed a troubled path construction began in October 1975 and ended with the installation of the exhibition

halls in 1995, to be officilly inaurated officially inaugurated Adame 6 , Ad $p$ 45] 43, p. 45].

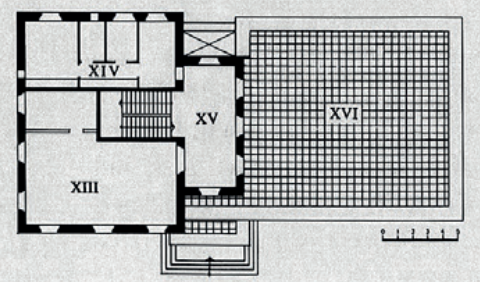

C. (Architectural plans - Angelos L. Kotronis)

\section{SECOND FLOOR}

XIII Lecture/projection room

XIV Service areas

XV Second-floor vestibule

XVI Roof Terrace 
The large building (about 1,000 square meters in area), located on the north side of the port of Hydra, is in harmony with the surrounding environment and the architecture of the place, still welcoming tourists and scholars who want to learn more about the historical and cultural events of the last two centuries of this region of Greece.

Today, the Museum of the National Archives of Hydra is visited daily by a large number of Greek and foreign visitors and exhibits important $19^{\text {th }}$ century paintings and numerous artifacts in addition to about 18,000 manuscripts and 122 codices, ledgers, etc. housed in the archive that may be of particular interest to historians and researchers [Adamopoulou-Pavlou 20 I5].

\section{Methodology of three-dimensional survey and documentation}

The complexity described above required a three-dimensional survey and documentation methodology that could, on the one hand, integrate multiple data acquisition methods and tools and, on the other, allow their aggregation and subsequent reuse. For this reason, we opted for the realization of BIM-based models that can be used for the documentation and management of the building and the realization of AR and VR applications. According to the specific purposes, different acquisition techniques were chosen following the guidelines identified in the survey protocol developed within the INCEPTION project [Di Giulio et al. 2017].

The survey of the building and its BIM modeling

For the survey of the museum building, a hybrid methodology, now consolidated, was used, using terrestrial laser scanner as a basis for the integration of aerial photogrammetry [Nex, Remondino 20 I 4] recorded through topographic framing. The terrestrial laser scanner used for the survey of the museum's interior and the exterior of the entire complex was the Faro LS 330. In contrast, aerial photogrammetry from a drone [Fatta et al. 2017], for the model of the roofs and the parts of the complex in elevation that are difficult to reach due to the orography of the terrain and vegetation, was carried out by photo acquisition from DJl Mavic Pro.

The terrestrial laser scanner survey (98 scans with $9.3 \mathrm{~mm}$ residual error) was recorded directly on the existing topographic network (materialized with in situ cornerstones outside and the main hall). The model thus obtained served, together with the topographic cornerstones visible from the drone (No. 5), as support for the photo-modeling alignment procedure (for a total of 483 processed images) to improve accuracy and reduce drift errors (fig. 5).

This survey then allowed us to proceed with an architectural BIM modeling, realized with Autodesk Revit 2016 software. The model, developed with a LOD adequate for the inclusion of all the information derived from the building surveys as well as from the documentation artifacts contained herein, was therefore structured with an information organization that could allow it to be used by the museum and its technicians in place of the existing 2D CAD drawings, for management and maintenance purposes.

The BIM model is integrated by a photographic campaign composed of $56360^{\circ}$ spherical photos to construct a Virtual Tour of the complex in off-site applications, mainly related to web-browsing. The high-resolution images (10.000 ×5.000px equirectangular) have been acquired in HDR through Ntech iStar. The Virtual Tour was then created with 22 of the acquired images and subsequently populated with contextual information.

The 3D documentation of the artifacts of the museum collection

Particular attention was paid to the 3D documentation of the artifacts inside the museum and the creation of their digital models. Laser scanning technologies (Faro Ls330) were used for the acquisition of the decorative devices and details on an architectural scale (such as moldings and access doors to the island's rich dwellings or devices related to boats or navigation in general), as well as photogrammetric techniques (Canon 5D Mark2 - 50mm fl.4) 
for the statuary, custom, and objects. In both cases, the use of targets was used for recording and processing data.

In total, the artifacts that were the subject of the documentation campaign and of which three-dimensional models were created amount to about thirty, chosen from those with the most essential symbolic meaning [Adamopoulou-Pavlou 20 I5]. These include a figurehead representing a vernacular female figure cradling a small lion in her arms, several akrostolia, (bow decorations), five traditional Idriot costumes, several guns from the HAMH collection, an elaborate silver vase named after Admiral Miaoulis, and the bust of the Idriot Nikolaos Kolmaniatis.

The semantic enrichment of the BIM model and the population with attached documentation The realized architectural BIM model thus becomes the aggregating element of all the digitization of the artifacts and makes possible their connection both digital and meaning, thanks to exploiting the Semantic Web. The model, compatible with the IFC $2 \times 3$ standard, was uploaded to the INCEPTION platform [Maietti et al. 2020], where all the modeled components, both architectural and exhibition furniture, were converted into TTL [Bonsma et al. 20 I8], to be further enriched both semantically and with attachments of different types (PDF, structural reports, thermographs, images, detailed 3D models, etc.), referring to the

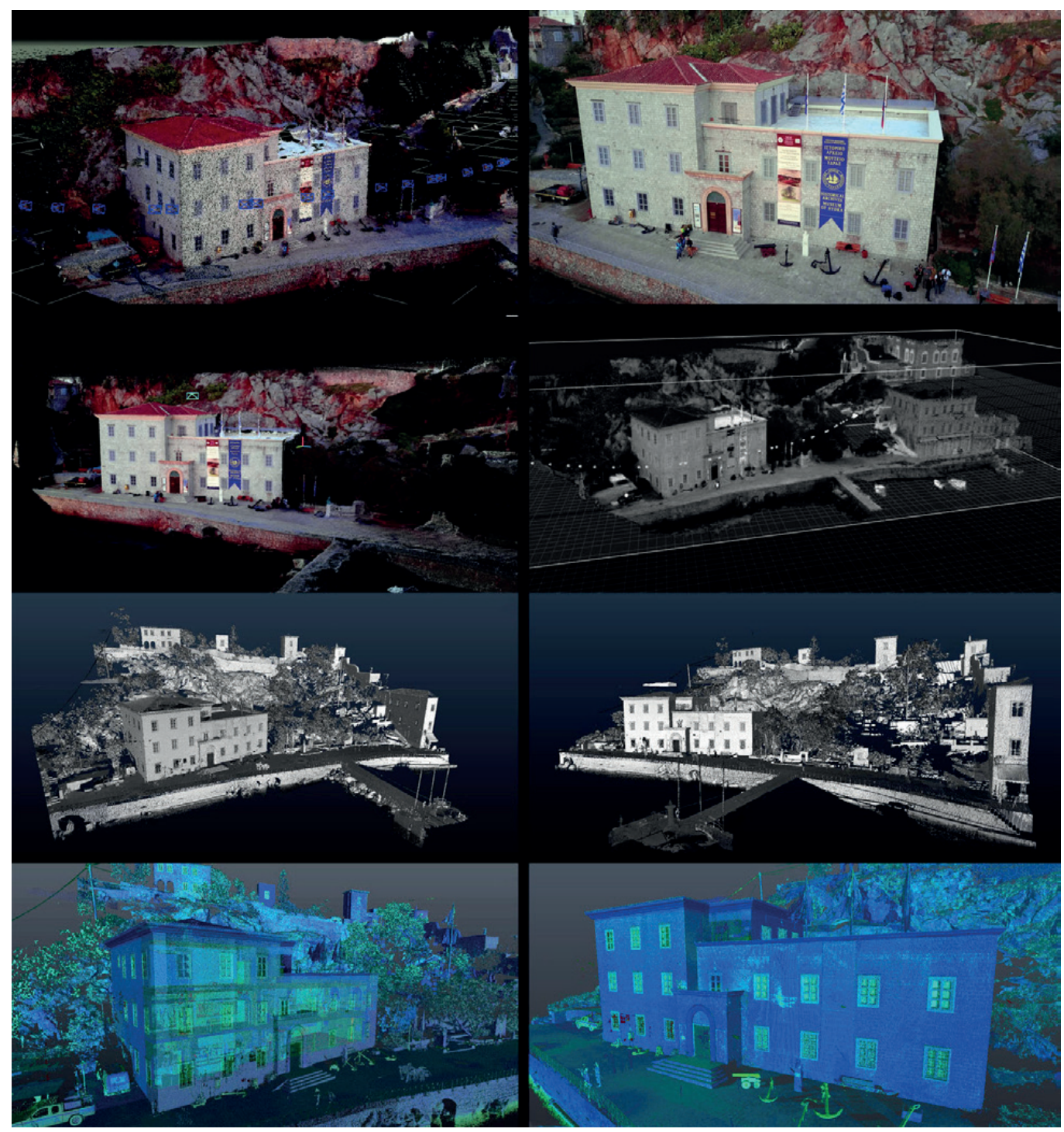


Fig. 6. The BIM model, created with Autodesk Revit 2016 software, was uploaded on the NCEPTION platform to be semantically enriched and to link attachments to individual elements. In the image, a screenshot of the platform in blended visualization mode between the BIM model and the 3D survey.
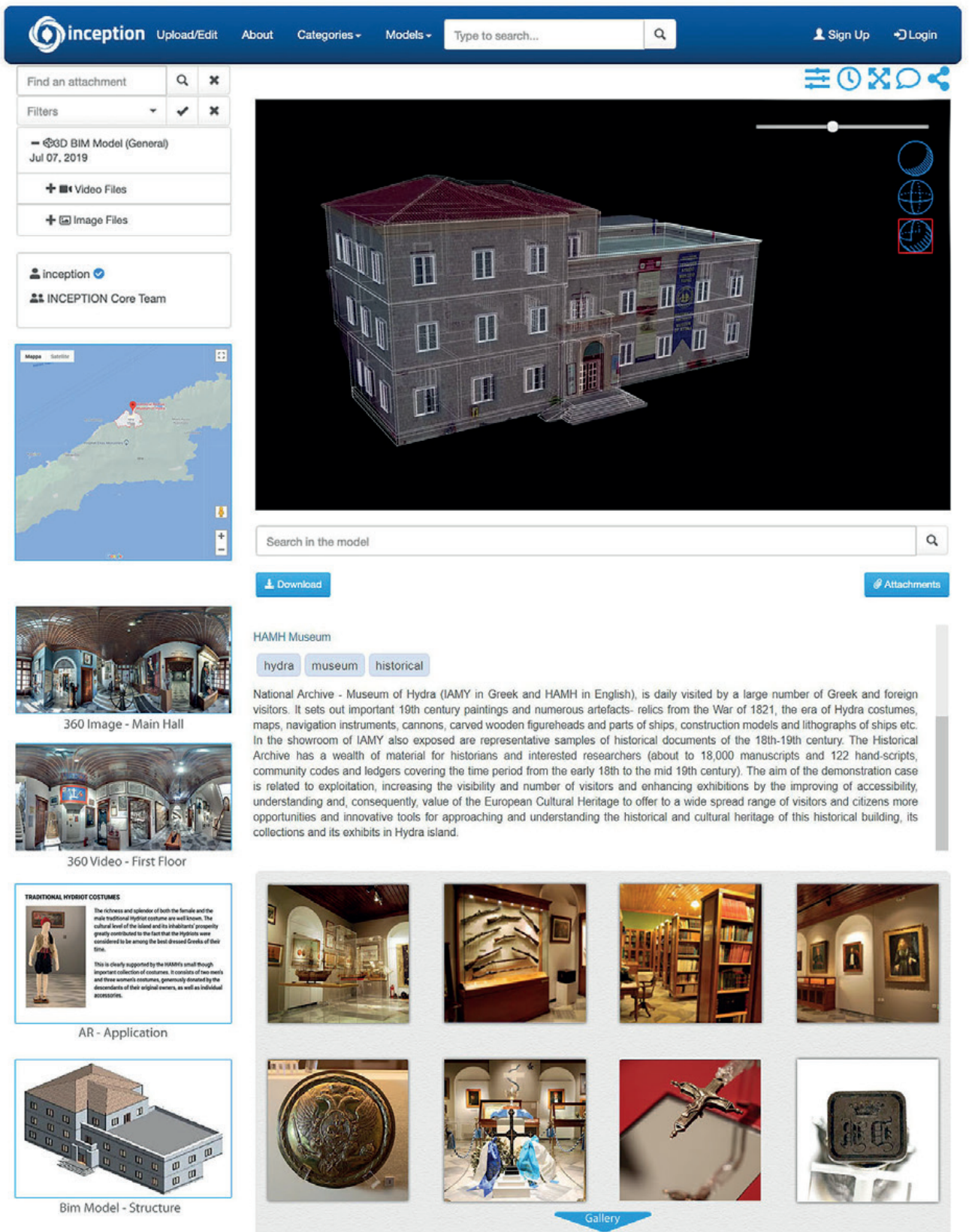

single elements of the BIM model. A URI (Unique Reference Identifier) is then attributed to each three-dimensional object which, placed at the base of the system of semantic triples, makes it possible to refer univocally to each element the information already contained in the IFC file, the attachments subsequently linked through the platform, as well as any direct links with historical archives made available as Open Linked Data.

The diversity of models and the complexity of the information they contain require, at the same time, an effective system of use (fig. 6). In this sense, the INCEPTION platform can filter the different types of data according to the kind of user. In this case, since information on technical and/ or operational data is available, the museum technician can, for example, easily choose between information that is important for assessing the condition of the structure or planning maintenance. At the same time, the scholar can decide to view only historical-archival information related to geometry, photographic documentation 360 of the environments, or digitalization of artifacts. 

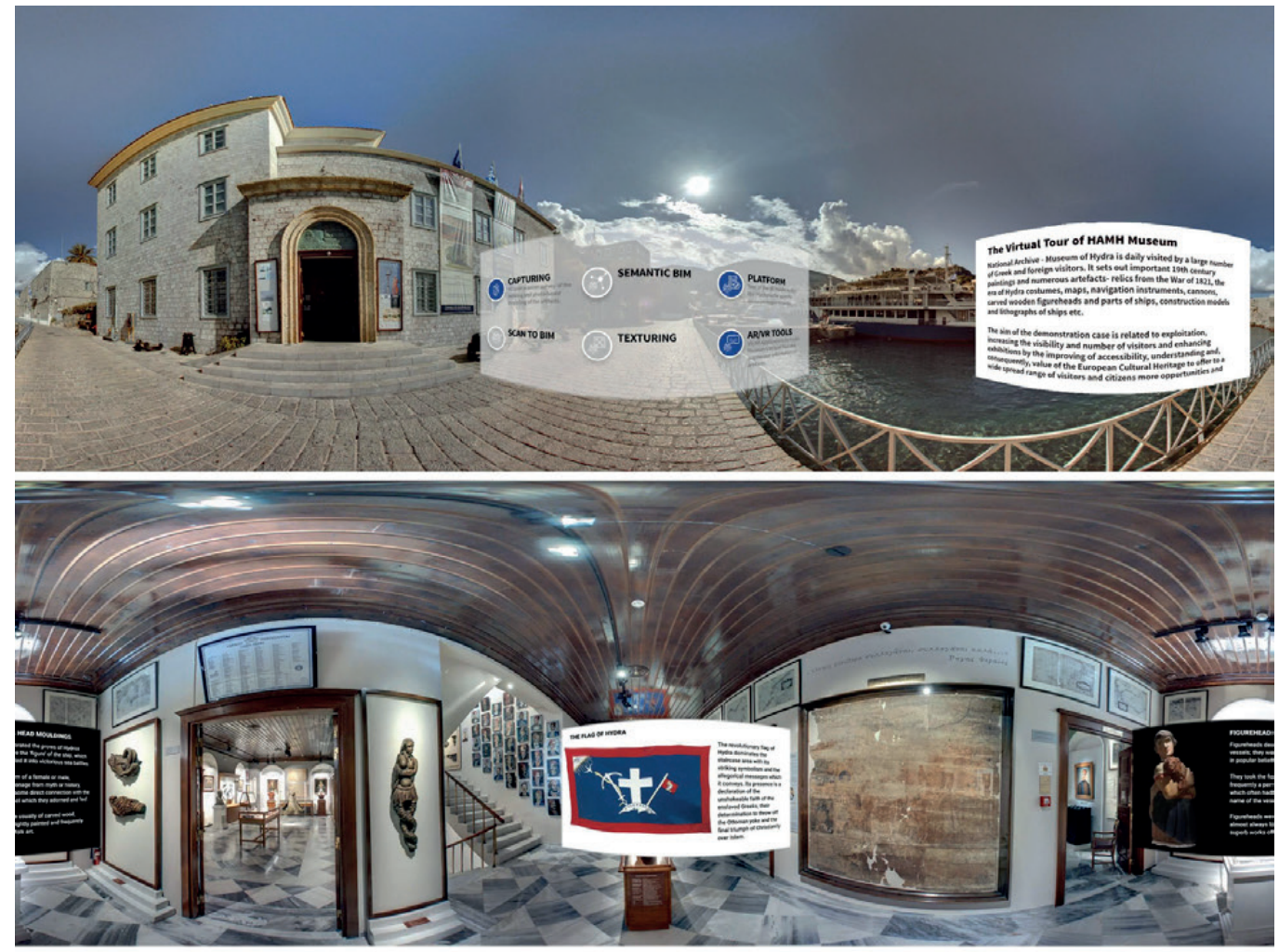

Fig. 7. The Virtual Tour of the interactive museum has been realized with 22 of the 56 spherical photos, captured during the survey campaign, and has been designed mainly for use via web browser, all-in-one

VR headset or mobile devices.
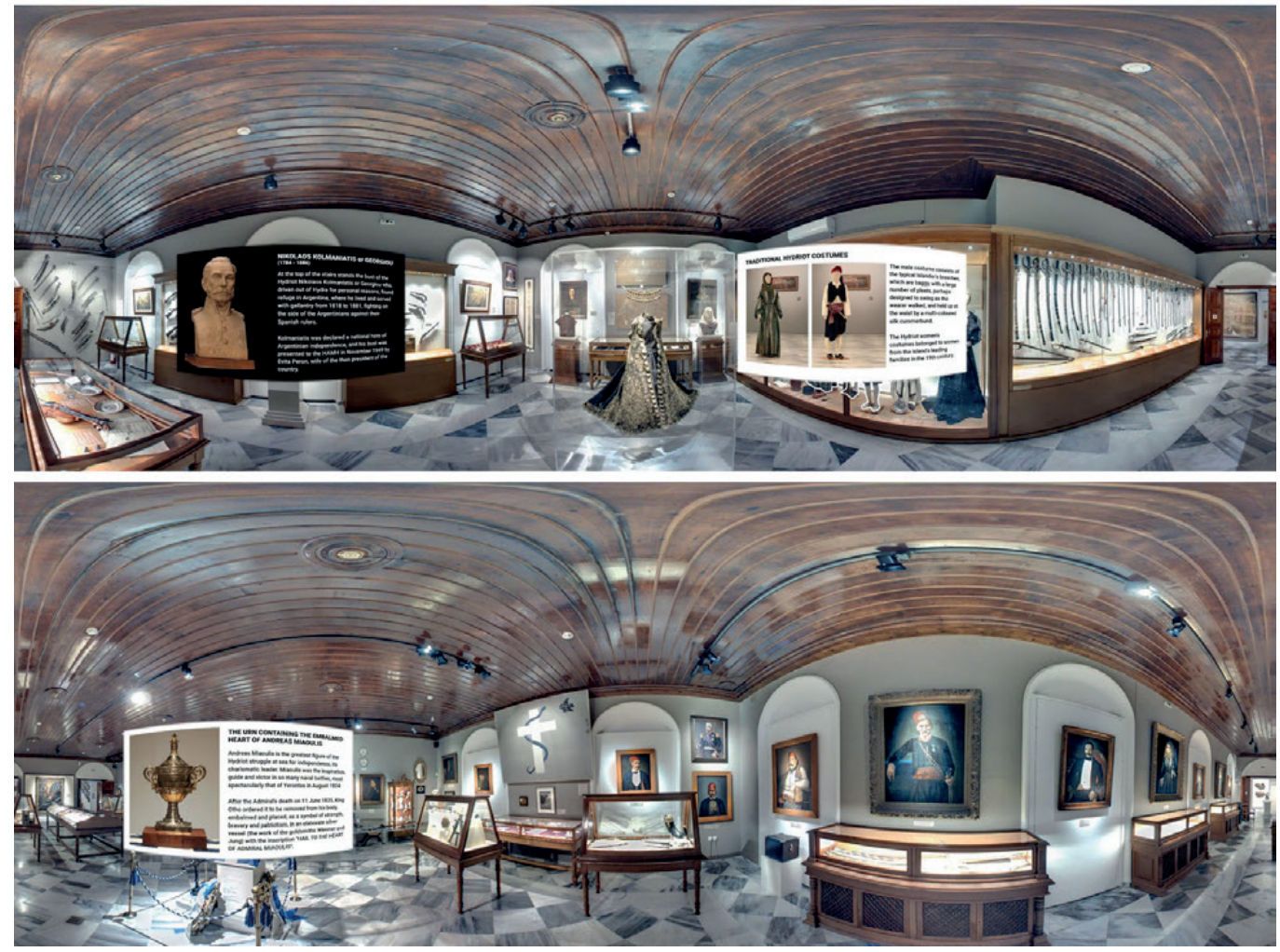


\section{Results and applications of AR/VR for the fruition of documented content}

Starting from the survey and the BIM model, integrating the detailed models of statues, clothes, and other objects exhibited in the museum collection, made possible by combining the INCEPTION platform, a multiscalar model of the entire museum complex is realized concretely. The same has then opened to the realization of other experiences of data fruition, also thanks to the creation of Virtual Reality (VR) or Augmented Reality (AR) applications [Parrinello et al. 20 I6]. In some cases, the models already created were further processed, optimized, and redefined using surface modelers, including NURBS, such as Rhino or Sketchup [Ausonio et al. 20 I8].

In configuring the models, the a priori definition of the storytelling logic that AR/VR communication would develop was of paramount importance [Keil et al. 20।3]. The navigation of the Virtual Tour of the museum and the museum collection contained herein, usable both from desktop and mobile and with the possibility of activating an immersive mode (with Head-Mounted Display HMD of fixed or portable type), allowed to emphasize the narrative thanks to the possibility of guiding the user between the rooms concerning a predefined path and arranging additional content room by room with greater ease. In the Virtual Tour produced, realized in raster-based mode starting from $360^{\circ}$ photos (fig. 7), the objects come to life and draw the attention of the digital visitor through the use of three-dimensional pop-ups.

In addition, the on-site visit has been enriched through the development of an AR app for smartphones (fig. 8) that enhances the visualization of artifacts through their recognition in the museum collection based on shape, size, appearance, and location. The recognition technology used is just on the algorithms made available by Vuforia for development in the Unity environment. Thanks to the availability of a $4 \mathrm{G}$ or Wi-Fi connection (both available on-site), the objects of the museum collection then become access points [Brusaporci et al. 20 I7] for the fruition of online content aggregated on the INCEPTION platform that, in this way, are directly and dynamically retrieved from there, in their most updated version, exploiting an on-the-fly retrieval logic.

\section{Conclusions and future developments}

The case study of the digitization of HAMH allowed us to demonstrate how an effective synergy between important technological innovations and small local museum systems can work only if facilitated by specific actors, a role in this case played by VBC. Although the potential of $A R$ and $V R$ applications in the cultural heritage sector and, in particular, in the museum sector is proven and improves the visitor experience, individual museum administration is not always able to access these benefits. The critical role of an informed facilitator, in this case, has made the adoption of the latest technologies available in a conscious manner. In conclusion, although it is not possible at this time to provide significant data on the increased visibility of this museum system and its exhibits or the increase in the number of visitors also by the current pandemic condition, even the mere possibility of being able to appreciate the shows in a historical period of reduced global mobility is an element of favorable evaluation of the project itself. Furthermore, it is possible to say that, with the greater availability of products and services that the museum can offer precisely because of this digitization, the potential user base with which $\mathrm{HAMH}$ can relate has undoubtedly expanded. The main user of the museum remains the seasonal visitor to Hydra Island for a short stay for pleasure, but the digital visitor interested in understanding the recent history of Greece as well as the international scholar who, for the first time, can access unique content previously available only on-site, have been added in a much more consistent way than before.

Finally, three-dimensional digitization techniques combined with the web and XR (Extended Reality) tools become a new linguistic tool for dialogue and storytelling for different actors, opening up effective reuses for multidisciplinary purposes. 


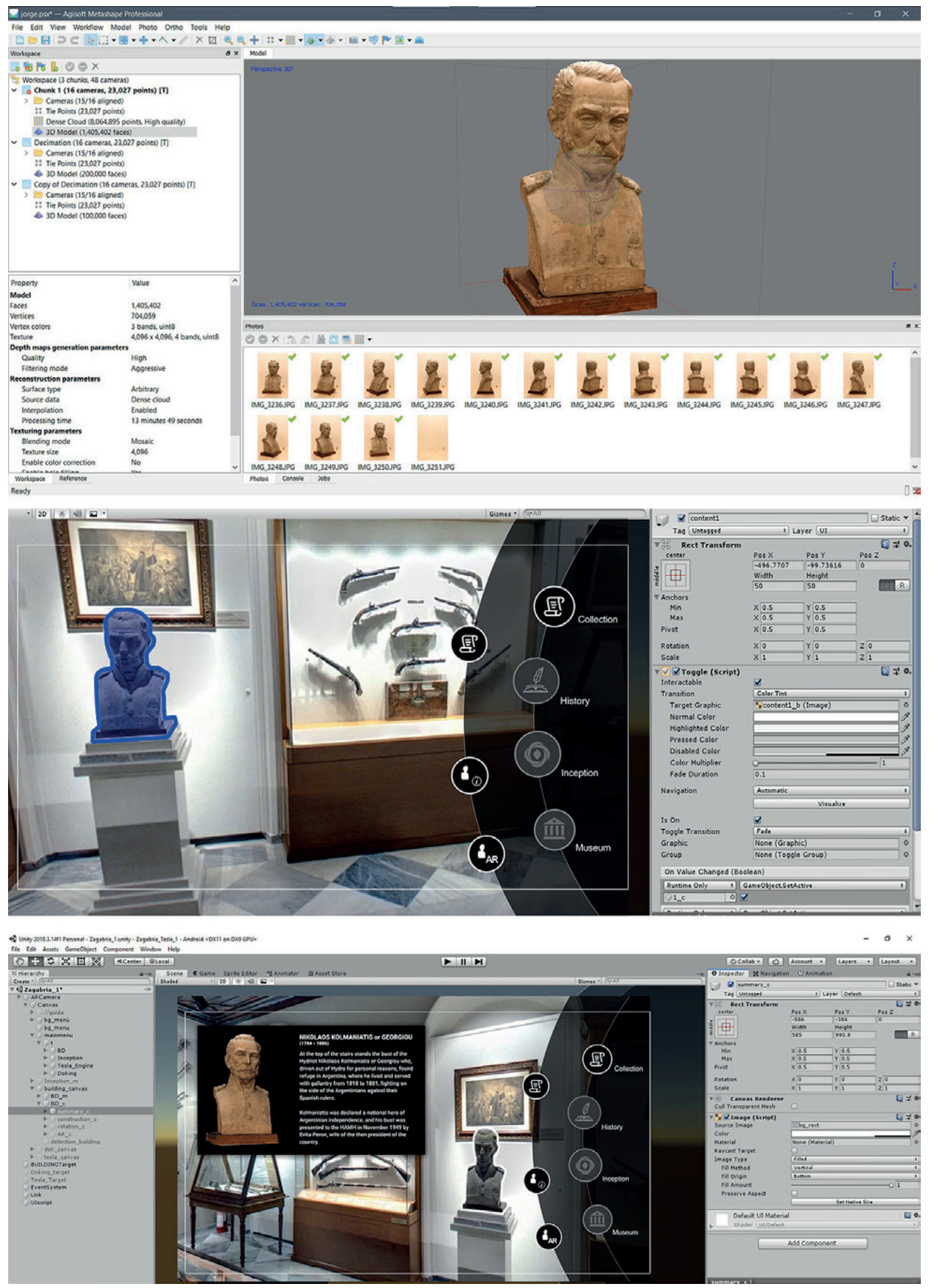

Fig. 8. Example of Augmented Reality application developed on the bust of

Captain Nikolaou G. Kolmaniati (Nicolas orge Colmaniatis) who, after immigrating to Argentina in $|8| 1$, enlisted as a sailor and reached the rank of Rear Admiral, an Idriot national hero of Argentina.

\section{Notes}

[I] Experimentation carried out within the European project INCEPTION - Inclusive Cultural Heritage in Europe through 3D semantic modelling, concluded in May 2019 and funded by the European Commission under the Horizon 2020 Program Research and Innovation Action under Grant Agreement No. 665220.

[2] Government Gazette, n. 82 of 16 April 1918 . 


\section{References}

Adamopoulou-Pavlou C. (1997). Hystorical Archives - Museum Of Hydra. Atene, Greece: Artigraf.

Adamopoulou-Pavlou C. (200I). Hydra. Hydra, Greece:Vergas.

Adamopoulou-Pavlou C. (2015). Catalogue of H.A.M. of Hydra. Hydra, Greece: HAMH.

Ausonio E. et al. (2018). Potenzialità dei software Free e/o Open Source per la modellazione, gestione e fruizione di entità 3D In Geomatics Workbooks, n. 14 - FOSS4G-it, pp. 4-20.

Bonsma P. et al. (20 I 8). Handling huge and complex 3D geometries with Semantic Web technology. In IOP Conference Series: Materials Science and Engineering, vol. 364 0I204I, pp. I-7.

Brusaporci S. et al. (2017) Augmented Reality for Historical Storytelling. The INCIPICT Project for the Reconstruction of Tangible and Intangible Image of L'Aquila Historical Centre. In Proceedings, I, I083.

Di Giulio R. et al. (2017). Integrated data capturing requirements for 3D semantic modelling of Cultural Heritage: the INCEPTION protocol. In Int. Arch. Photogramm. Remote Sens. Spatial Inf. Sci., XLII-2MW, pp. 25 I-257.

Fatta F., Bassetta M., Manti A. (2017). Survey Methodologies, Research and Technological Innovation for a Case of Medieval Archaeology: Torre Melissa in the province of Crotone. In Disegnarecon, I0(19), pp. 6. I - 6.17.

Keil J. et al. (20।3). A digital look at physical museum exhibits: Designing personalized stories with handheld Augmented Reality in museums. In Digital Heritage International Congress, vol. 2, pp. 685-688.

Maietti F. et al. (2020). Documentation, Processing, and Representation of Architectural Heritage Through 3D Semantic Modelling:The INCEPTION Project. In C. Bolognesi, C. Santagati (Eds.). Impact of Industry 4.0 on Architecture and Cultural Heritage, pp. 202-238. Hershey, PA: IGI Global.

Nex F., Remondino F. (20 I4). UAV for 3D mapping applications: a review. In Applied geomatics, 6( I), pp. I-I5.

Parrinello S., Picchio F., Bercigli M. (20|6). La 'migrazione' della realtà in scenari virtuali: Banche dati e sistemi di documentazione per la musealizzazione di ambienti complessi. Musei virtuali dell'architettura e della città. In Disegnarecon, 9( I7), pp. I4- I

Spiliotis S.F. (1998). The secret Hydra. Hydra, Greece: Kyveli.

\section{Authors}

Marco Medici, Università di Ferrara, marco.medici@unife.it

Federico Ferrari, Università di Ferrara, federico.ferrari@unife

To cite this chapter. Medici Marco, Ferrari Federico (2021). Realtà Virtuale e Aumentata per la valorizzazione dell'Historical Archives Museum di Hydra/Virtual and Augmented Reality Applications for Enhancement of the Historical Archives Museum of Hydra. In Arena A. Arena M. Mediati D. Raffa P (a cura di) Connettere Un disegno per annodare e tessere Linguaggi Distanze Tecnologie. Atti del $42^{\circ}$ Convegno Internazionale dei Docenti

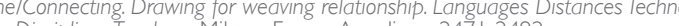
teational Conference of Representation Disciplines Teachers. Milano: FrancoAngeli, pp. 2471-2492. 